PNL-7430

UC-510

\title{
Contaminated Materials Treatment Program Annual Report for FY 1989
}

Compiled by

W. A. Ross and J. A. Powell

August 1990

Prepared for the U.S. Department of Energy under Contract DE-AC06-76RLO 1830

Pacific Northwest Laboratory

Operated for the U.S. Department of Energy by Battelle Memorial Institute 


\title{
DISCLAIMER
}

This report was prepared as an account of work sponsored by an agency of the United States Government. Neither the United States Government nor any agency thereof, nor Battelle Memorial Institute, nor any of their employees, makes any warranty, expressed or implied, or assumes any legal liability or responsibility for the accuracy, completeness, or usefulness of amy information, apparatus, product, or process disclosed, or represents that its use would not infringe privately owned rights. Reference herein to any specific commercial product, process, or service by trade name, trademark, manufacturer, or otherwise, does not necessarily constitute or imply its endorsement, recommendation, or favoring by the United States Government or any agency thereof, or Batlelle Memorial Institute. The views and opinions of authors expressed herein do not necessarily state or reflect those of the United States Government or any agency thereof.

\author{
PACIFIC NORTHWEST LABORATORY \\ operated by \\ BATTELLE MEMORIAL INSTITUTE \\ for the \\ UNITED STATES DEPARTMENT OF ENERGY \\ under Contract DE-AC06-76RLO 1830
}

Printed in the United States of America

Available to DOE and DOE contractors from the

Office of Scientific and Technical Information, P.O. Box 62, Oak Ridge, TN 37831; prices available from (615) 576-8401. FTS 626-840t.

Available to the public from the National Technical Information Service, U.S. Depanment of Commerce, 5285 Port Royai Rd., Springfield, VA 22161.

NTIS Price Codes, Microfiche A01

Printed Copy

\begin{tabular}{ccccc}
\hline Price Code & Page Range & & Price Code & Page Range \\
\cline { 4 - 5 } \cline { 4 - 5 } A02 & $1-10$ & & A15 & $326-350$ \\
A03 & $11-50$ & & A16 & $351-375$ \\
A04 & $51-75$ & & A17 & $376-400$ \\
A05 & $76-100$ & & A18 & $40 ;-425$ \\
A06 & $101-125$ & & A19 & $426-450$ \\
A07 & $126-150$ & & A20 & $451-475$ \\
A08 & $151-175$ & & A21 & $476-500$ \\
A09 & $176-200$ & & A22 & $501-525$ \\
A10 & $201-225$ & & A23 & $526-550$ \\
A11 & $226+250$ & & A24 & $551-575$ \\
A12 & $251-275$ & A25 & $576-600$ \\
A13 & $276-300$ & A99 & $601-U p$ \\
A14 & $301-325$ & &
\end{tabular}


PNL -7430

UC -510

CONTAMINATED MATERIALS TREATMENT PROGRAM

ANNUAL REPORT FOR FY 1989

\author{
Compiled by \\ W. A. Ross and J. A. Powel1 \\ Contributing Managers \\ W. A. Ross \\ L. K. Hoiton, Jr. \\ J. H. Jarrett \\ C. C. Chapman \\ R. 0. Peters \\ Contributing authors are listed \\ at the beginning of sections.
}

August 1990

Prepared for the U.S. Department of Energy under Contract DE-AC06-76RLO 1830

Pacific Northwest Laboratory Richland, Washington 99352 


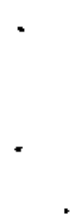




\section{SUMMARY}

The Contaminated Materials Treatment Program comprises five different efforts: 1) West Valley Support, 2) Federal Republic of Germany (FRG) Canister Loadout and Transportation, 3) Greater-Than-Class-C Low-Level Waste Management Support, 4) Production Rate Enhancement, and 5) Miscellaneous Waste Treatment. Each effort relates to nuclear waste treatment, and severa] have been previously reported as Tasks under the Nuclear Waste Treatment Program Annual Report (PNL-7131). The following are brief summaries of each effort.

\section{WEST VALLEY SUPPORT}

The West Valley Support activities include: Remote Technology Design, Process Support, Waste (Product) Qualification, and Tank Farm Process Support. Each task supports a specific group at the West Valley Demonstration Project that is designing, building, and preparing to operate a vitrification facility that will solidify the existing high-level wastes (HLW) at Hest Valley, New York.

The Remote Technology Support Task completed design of a decontamination station to remove surface contamination from filled HLW canisters. The station will use the cerium IV process that chemically dissolves a few microns of canister surface and thereby removes smearable contamination. A maintenance station was also designed to permit minor in-cell maintenance. A design was prepared for a system to allow viewing of the glass stream as it pours from the melter into the canister. It uses a series of mirrors and lenses to allow a video camera outside the cell to see the pouring glass stream. Stress analysis of equipment nozzles was completed for most of the high-temperature nozzles, and several were identified as potentially overstressed. Stress analyses of remote jumpers were also completed to show compliance to American National Standards Institute $B 31.3$ code requirements.

The Process Support Task supports the definition of process limits, conditions, and controls to permit the vitrification process to operate safely and to ensure that the product glass is acceptable. In accordance with the Waste Acceptance Preliminary Specifications (WAPS), studies were conducted on the analytical laboratory accuracy and precision and determined that the 
relative standard deviation for most major constituents of the glass was less than $5 \%$ and was due to long-term instrument variations. Studies were also conducted on the homogeneity and ability to sample process vessels. The tests showed that the tanks were homogeneous and that the samplers were mostly consistent, but some bias was noted for the Hydragard sampler for some elements. As backup process data, several processes were evaluated to remove excess sutfur from the process should sludge-washing not prove sufficiently successfut. Direct decantation of the submerged bed scrubber liquid was the most attractive process. A large spreadsheet to allow mass balances throughout the West Valley waste preparation and vitrification process was further improved, verified, and validated. A conservative analysis of the volatilization losses during glass-pouring was made based on first principles. The conservative calculations indicated that a maximum of $0.1 \%$ of the cesium could volatilize during glass-pouring. Correlations of previous melter data, analytical calculations, and laboratory experiments were studied to determine potential methods to increase the melting rate of West Valley feed. Study recommendations included the need to decrease nitrates and sugar in the feed and increase formates, hydroxides, and frit. PNL also supported testing of a pilot-scale selective catalytic reduction system to reduce the ${ }^{\mathrm{NO}} \mathrm{N}_{\mathrm{x}}$ content in the off-gas system to comply with New York State requirements.

The Waste Qualification Task supports the preparation of the West Valley Waste Qualification Report in accordance with the DOE WAPS. A major activity completed this year is the leach-testing of heat-treated glasses. According to WVNS plans the glasses were prepared by Catholic University of America, heat-treated at Alfred University, and then leach-tested by the MCC-1 and MCC -3 leach procedures at PNL. The tests showed some expected sma11 effects. The most significant was measured for the sample held at $600^{\circ} \mathrm{C}$ for $96 \mathrm{hr}$, in which the leach rate increased about $50 \%$.

The Tank Farm Process Support Task provides technical information related to the HLW storage tanks and the processing of the supernatant in the primary HLW tank. During the year a problem with the dump valve in the Supernatant Treatment System (STS) was limiting operations. Tests were conducted that identified alternative operational modes that allowed processing to continue. other tests have been conducted to begin evaluating the corrosion of the 
storage tank caused by zeolite used in the STS process. Pitting of the corrosion specimens was noted.

\section{FRG CANISTER LOADOUT AND TRANSPORTATION}

Isotopic heat and radiation sources for the Federal Republic of Germany have been fabricated previously and are in storage at PNL awaiting shipping approvals. During this year the future shipping cask was received at PNL and functionally tested. An Environmental Assessment is being completed before shipment.

\section{GREATER-THAN-CLASS-C-LOW-LEVEL WASTE}

A program was started this year on the packaging, transport, treatment, disposal, and fee estimation of the commercial Greater-Than-Class-C low-level waste being generated in the United States. This program is part of a larger national effort being performed by the Idaho National Engineering Laboratory and PNL. During the year, draft reports were prepared in those technical tasks and plans were made for future activities.

\section{PRODUCTION RATE ENHANCEMENT}

Work on increasing the production rate of 1 iquid-fed ceramic melters (LFCM) was started in FY 1989. The objective of the program is to identify key factors and methods that will increase the throughput of production melters. A series of activities are being pursued.

Existing information was first acquired and anatyzed. A computer data base was compiled summarizing past runs of LFCMs. It was statistically analyzed to determine the effects of melter feed compositions on processing characteristics. The analytical results showed that only a few variables could be correlated to production rate; most had insufficient trials to support true statistical analysis.

The second step of the Production Rate Enhancement task was to study the melting phenomena using both analytical and laboratory methods. The laboratory investigation was conducted with semi-batch crucible tests using variations of the West Valley Demonstration Project flow sheet. The results 
indicated qualitative differences with use of glass-forming chemicals and reductants, but quantitative data could not be obtained because of the small scale. Further laboratory-scale testing should be done to learn why different glass-formers give different cold-cap characteristics. Larger scale (continuous bench scale) tests are also required to quantify the effects of different feed properties and operating conditions.

The analytical modeling was conducted using simple thermodynamic models and fluid dynamics modeling on a computer. The thermodynamic models showed the effect of feed concentration on the heat required to produce glass. The results indicated a preference for concentrated feeds although the benefit decreases with increasing concentration. It should be noted, however, that the slurry rheology was not taken into account in the model. The fluid dynamics modeling investigated the effect of bulk glass temperature, viscosity, and power distribution on production rate. The results indicated that high-temperature operation increased heat transfer to the cold-cap region by reducing the viscosity and the thickness of the thermal boundary layer. Further development and use of these models will give additional insight into ways to increase the glass production rate of melters.

\section{MISCELLANEOUS WASTE TREATMENT}

The Miscellaneous Waste Treatment Program is designing and constructing a plasma furnace for treating contaminated or activated metals. Various technologies for volume reduction of Greater-than-Class-C metals have been evaluated in earlier programs at PNL. Metal melting, specifically via plasma heating, has emerged as a promising approach. In FY 1989, the functional design criteria for the plasma furnace were prepared, a contract with a manufacturer was established to design and build the plasma torch, design concepts for the furnace were developed, and design of the furnace and torch was initiated. 


\section{CONTENTS}

SUMMARY ............................

1.0 WEST VALLEY SUPPORT . . . . . . . . . . . . . 1.1

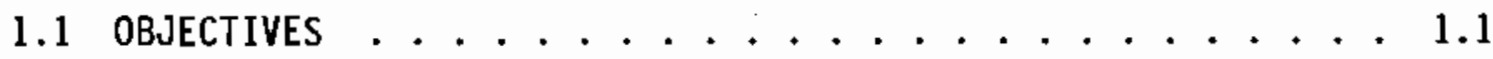

1.2 REMOTE TECHNOLOGY SUPPORT . . . . . . . . . . . 1.1

1.2.1 Decontamination Station ................ 1.1

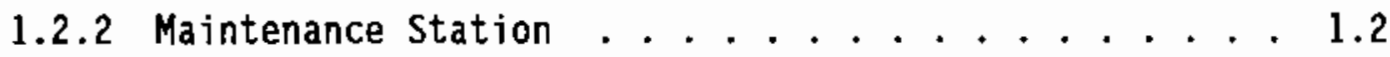

1.2 .3 Glass Pour Viewing System . . . . . . . . 1.3

1.2 .4 Jumper Drawings . . . . . . . . . . . . . 1.3

1.2.5 Vitrification Ce1l Tank Nozzle Anatysis ...... 1.3

1.2.6 Remote Jumper B31.3 Code Compliance . . . . . . . 1.4

1.3 PROCESS SUPPORT . . . . . . . . . . . . . . . . 1.4

1.3.1 Ana7ytical Laboratory Accuracy and

Precision - Glass Analysis . . . . . . . . 1.5

1.3.2 Variance for Concentrator Feed Makeup Tank, Melter

Feed Hold Tank, and Slurry Sampler System . . . . . 1.7

1.3.3 Removal of Sulfur from the Vitrification

Process ....................13

1.3.4 Mass Balance Spreadsheet . . . . . . . . . . 1.16

1.3.5 Volatilization Losses During Glass Pouring ..... 1.18

1.3.6 Effect of Melter Feed Composition on Processing
Characteristics ...................... 18

1.3.7 Nitrous 0xide Reduction by Selective Catalytic

Reduction .............. 1.19

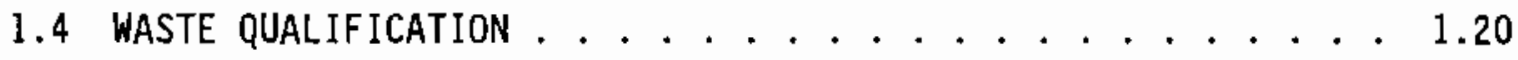


1.5 TANK FARM PROCESS SUPPORT . . . . . . . . . . 1.22

1.5.1 Support for STS Operations . . . . . . . . 1.23

1.5.2 Tank Corrosion Testing . . . . . . . . . . 1.24

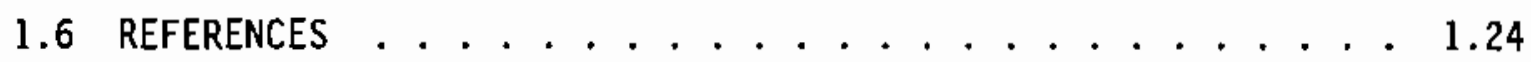

2.0 FRG CANISTER LOADOUT AND TRANSPORTATION . . . . . . . 2.1

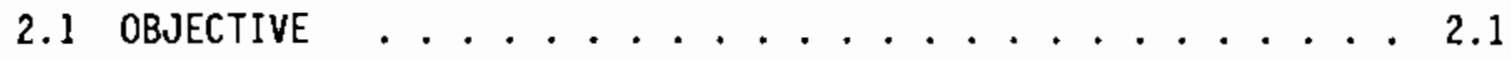

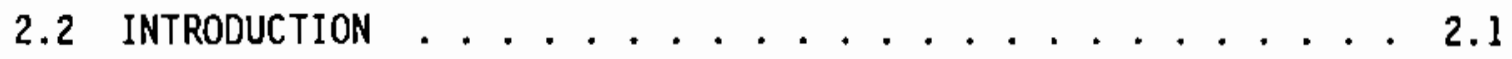

2.3 PROGRESS IN FY $1989 \ldots \ldots . . \ldots . \ldots . . \ldots . . \ldots 2$

3.0 GREATER-THAN-CLASS-C LOW-LEVEL WASTE . . . . . . . . . 3.1

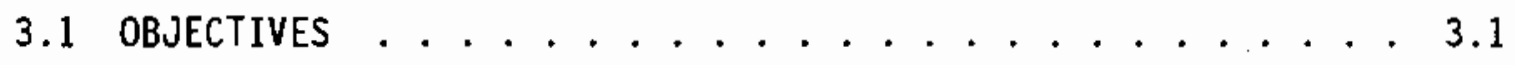

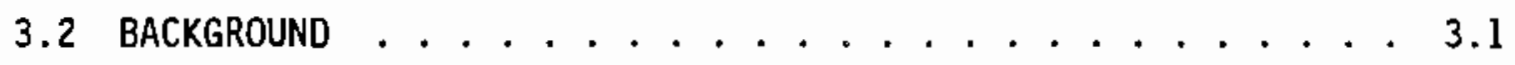

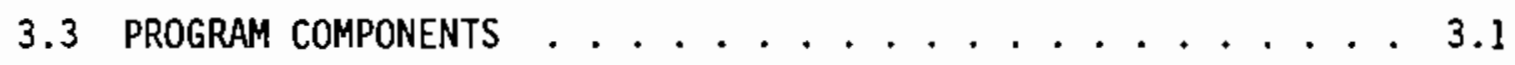

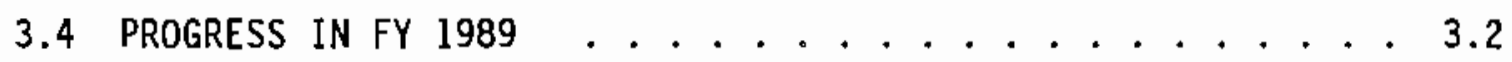

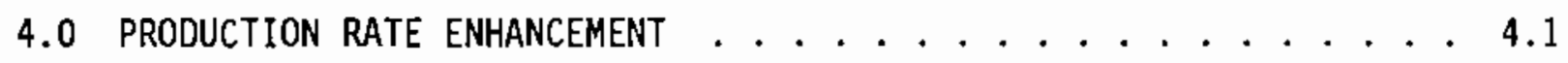

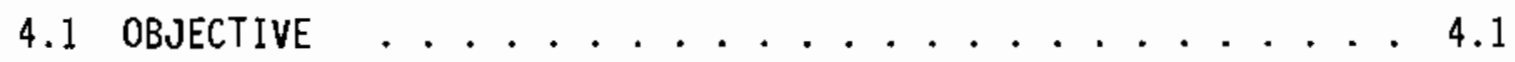

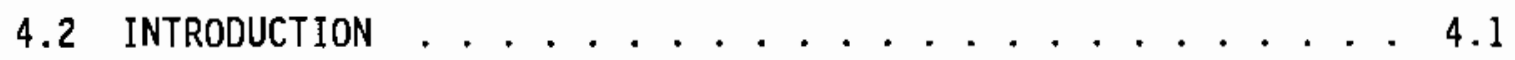

4.3 DATA BASE ANALYSIS . . . . . . . . . . . . . 4.2

4.4 LABORATORY-SCALE EXPERIMENTS . . . . . . . . . 4.3

4.5 ANALYTICAL MODELING . . . . . . . . . . . . . . . 4.8

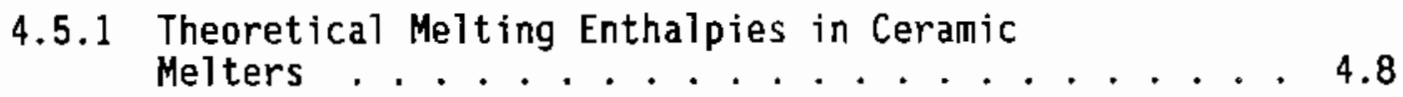

4.5.2 Effect of Cold-Cap Porosity on Thermal
Conductivity . . . . . . . . . . . 4.10

4.6 PILOT-SCALE TESTING . . . . . . . . . . . . . . . 4.12

4.7 REFERENCES ................... . . . . 4.13 


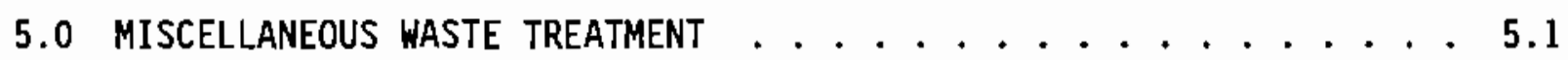

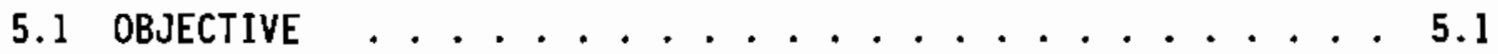

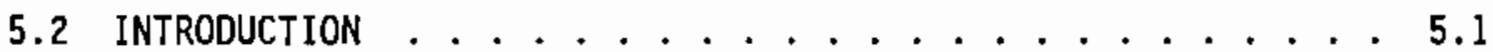

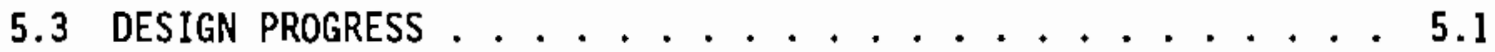

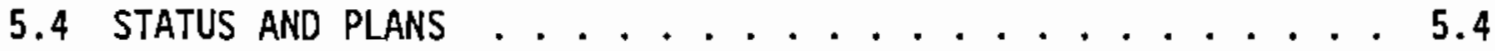




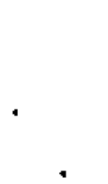




\section{FIGURES}

1.1 Uncertainty Estimates from Glass Analysis--RSD--

Normalized Results . . . . . . . . . . . . . . 1.6

1.2 Uncertainty Estimates from Glass AnaTysis--Sources of Variance--Normalized Results . . . . . . . . . . 1.6

1.3 Process Flow Sheet and Proposed Options for Sulfur Removal . . . 1.14

1.4 Comparison of Boron Average Normalized Releases from Isothermally Heat-Treated G1asses: MCC-1, 28 days, Deaerated Deionized Water, $10 \mathrm{~m}^{-1} \ldots \ldots . . \ldots 1.21$

1.5 Comparison of Boron Average Normalized Releases from Isothermally Heat-Treated Glasses: MCC $-3,7$ days, Deaerated Deionized Water, $2000 \mathrm{~m}^{-1} \ldots \ldots . . \ldots . . . .22$

1.6 Corrosion Data . . . . . . . . . . . . 1.25

4.1 Laboratory Test Arrangements . . . . . . . . . . . . . 4.4

4.2 Melt Rate Data for Formate Glass-Former Feeds . . . . . . . . 4.5

4.3 Me1t Rate Data for Frit Feeds . . . . . . . . . . . 4.6

4.4 Comparison of Melt Rates with 90\% Confidence Intervals . . . . 4.6

4.5 Melt Rate Data for Hydroxide Glass-Former Feeds . . . . . . . . 4.7

4.6 Melter Glass Production Rate, Slurry Melting Entha7py, and S1 urry Yield Stress Versus S1urry Oxide Loading . . . . . . . 4.10

5.1 Waste Treatment Plasma Furnace and Off-Gas System . . . . . 5.3 


\section{IABLES}

1.1 Mean Estimates for the Parameters Showing Significant

Difference Among the CFMT Sample Types Taken During

SF-11 from Batch 1 . . . . . . . . . . . . . . . . . 1.9

1.2 Mean Estimates for the Parameters Showing Significant

Difference Among the CFMT Samples at Different Tank

Volumes During SF-11 from Batch 2. . . . . . . . . . . . 1.12

1.3 Comparison of Two SBS Sulfur Removal Options . . . . . . . . . 1.17

1.4 Feed Matrix for Laboratory Testing . . . . . . . . . . . . . . 1.20

4.1 Feed Matrix for Laboratory Testing . . . . . . . . . . . . 4.4 


\subsection{WEST VALLEY SUPPORT}

W. A. Ross - Manager

\subsection{QBJECTIVES}

The Western New York Nuclear Services Center reprocessed nuclear fuel for five years until operations were terminated in 1972. Underground tanks at the site contain high-level waste (HLW) generated during the reprocessing operations. Based on original agreements, the state of New York has assumed responsibility for the wastes and the site. The Department of Energy (DOE) is assisting New York State, through the West Valley Demonstration Project (WVDP), in processing and solidifying the HLW. The site contractor for the WVOP is West Valley Nuclear Services Co., Inc. (WVNS). The Pacific Northwest Laboratory (PNL), through the West Valley Support Project, has been supporting WVNS and DOE in establishing vitrification and waste processing technology and capability at the West Valley Site.

The specific objectives of the West Valley Support Project during FY 1989 were to 1) complete designs of remote equipment, 2) assist in characterizing the WVNS feed, sampling, ceramic melter and off-gas systems, 3) provide chemicaT analysis of the radioactive wastes and testing of future processes with actual radioactive wastes, 4) provide testing and modeling studies of the reference WV waste product, and 5) conduct special studies, such as evaluating corrosion of the waste tanks and supporting operation of the supernatant treatment system.

1.2 REMOTE TECHNOLOGY SUPPORT - J. M. Seay, D. N. Berger, R. L. Bogart, R. M. Burnside, and B. G. PTace

\subsubsection{Decontamination Station}

The main function of the decontamination and swipe station is to remove surface contamination from the HLW canisters after they are filled with glass and the top welded. A detailed description of the decontamination process has been documented (Bray 1988; Bray and Seay 1988). At the station the canister is inspected, and splattered glass or other large accumulations are removed from the canister with vibratory tools. The canister is then inserted into a 
titanium decontamination tank. The tank is filled with cerium IV solution, completely covering the canister, and the canister is allowed to soak for 3 to $6 \mathrm{hr}$, during which the cerium IV is reduced to cerium III. The surface material of the canister is removed to a depth of 1 to $3 \mu \mathrm{m}$ along with the surface contamination. The canister is then rinsed with water and moved to the swipe station, where the level of remaining contamination is determined. The decontamination solution is routed back to the concentrator feed makeup tank and the vitrification process.

During the past year the equipment specifications and the equipment drawings were updated to reflect current $p l a n s$ and incorporate requested changes from WVNS. The location of the station in the vitrification cell also was changed to allow better crane access for loading and unloading canisters. The associated jumpers a] so were modified to accommodate the changes in location. The final drawings and specifications were provided to WVNS for their use in procuring the equipment.

\subsubsection{Maintenance Station}

The maintenance station will be located in the vitrification process cell to accommodate small, minor in-cell maintenance activities. The station will be located in front of a cell window and have manipulators avajlable to perform the work. Some specific activities expected to be performed at the station include: replacing light bulbs in the remote light modules, size reduction of components and parts for waste management purposes, repairing smal1 components or parts, connecting/disconnecting crane-carried tools, repairing/replacing seals in "PUREX" connectors, cleaning small components or assemblies, and providing for small in-cell tool storage. To accomplish these activities, the station has electrical, fluid, air and spare connections for providing the station's utilities. It also has the capability to drain the fluids used in its functions to the waste header. It may also have the function of welding lids on the canisters, but this capability will be added later.

During the past year the specifications, drawings and supporting calculations were completed and reviewed, and WVNS comments were incorporated. The final information was provided to WVNS for their use in procuring the station. 


\subsubsection{Glass Pour Viewing System}

The glass pour viewing system is to provide a visual monitor of the glass stream as it pours from the melter into the canister. This will give assurance that $\mathrm{glass}$ is pouring and that it has consistent characteristics. It should allow for early detection of canister filling problems. In FY 1988 two systems were proposed and were illustrated in the 1988 Annual Progress Report (Brouns and Powell 1989). During the past year it was decided to use the periscope approach so that it would be similar to the melter viewing system. Following selection of the basic system, the preliminary design was completed and provided to WWNS for comment and review.

\subsubsection{Jumper Drawings}

During the past year we have continued to modify jumper drawings as necessary to conform to changes requested by WWNS. Some jumpers, such as those for the decontamination station, were redesigned to account for moving the station. Other jumpers, such as those for the maintenance station, were completed as the basic station drawings were completed.

\subsubsection{Vitrification Cell Tank Nozzle Analysis}

Continued stress analysis was performed for the nozzles in the vitrification faciTity. All the nozzles attached to steam or process jumpers were analyzed as they will be the most highly stressed segment. All nozzles attached together in assemblies or subassemblies were analyzed as well as a representative group of the others.

The Bijlaard analysis method (Wichman et al.) was employed for single nozzles, and NISA ${ }^{\oplus}$ finite-element software was used for assemblies and subassemblies. The Bijlaard analysis was performed on a LOTUS 1-2-3® spreadsheet template; NISA analyses were performed on NISA on an IBM Model $60^{\circ}$. The two

(a) NISA is a registered trademark of Engineering Mechanics Research Corporation, Troy, Michigan.

(8) LOTUS is a registered trademark of Lotus Development Corporation, Cambridge, Massachusetts.

( $) \quad$ IBM is a registered trademark of International Business Machines, Armonk, New York. 
methodologies determined the stress levels in the tank wall around the nozzle. NISA also determined the stress levels in the nozzle walls.

The results were compared with allowable stresses from American Society of Mechanical Engineers (ASME) Section VIII, Div. 1, to see whether overstressing occurred. The comparison determined which nozzles were overstressed and also provided information from which to develop scenarios predicting which situations lead to overstressing.

\subsubsection{Remote Jumper B31.3 Code Compliance}

Code compliance reports were completed on all remaining remote jumpers. The reports provided documentation demonstrating jumper compliance with American National Standards Institute (ANSI) B31.3 code requirements.

Code compliance was proved using AUTOPIPE (pipe finite-element software) calculations. AUTOPIPE calculates stress and loading conditions in the jumpers and compares results to B31.3 requirements. Current AUTOPIPE files were either updated or generated from the most current AutoCAD drawing files.

1.3 PROCESS SUPPORT - J. M. Perez, J. H. Westsik, B. A. Pulsipher,

D. L. Eggett, B. G. Place, D. E. Larson, M. L. Elliott, K. D. Wiemers,

L. A. Bray, R. W. Goles, D. D. Yasuda, P. I. Poh1, R. D. Peters, and

W. L. Kuhn

The objectives of this work are to support the definition of process limits, conditions, and controls that permit the vitrification process to operate safely and efficiently and to ensure that the product glass is acceptable. Appropriate limits assure that the process maintains standard conditions without either the need for shutdowns for safety concerns or the production of off-standard glass product. The Waste Acceptance Preliminary Specifications (WAPS) and WVNS's Waste Compliance Plan (WCP) (West Valley Nuclear Services 1988) identified the basic requirements and WVNS's plan for

(A) AUTOPIPE is a registered trademark of Engineering Design Automation, Berkeley, California.

(B) AutoCAD is a registered trademark of Autodesk, Inc., Sausalito, CaTifornia. 
meeting those requirements. The detailed process activities for meeting these requirements are important elements in the Process Support Task.

\subsection{Analytical Laboratory Accuracy and Precision - Glass Analysis}

The Waste Acceptance Preliminary Specifications require an estimate of the chemical composition of the waste glass and an "estimate of precision and accuracy, and the basis for the estimate of the precision shall be reported in the Waste Compliance Plan."

A statistically designed experimental plan was prepared and was executed to quantify 1) short-term instrument variations, 2) long-term instrument variations, 3) short-term preparation variations, 4) long-term preparation variation, and 5) variations between replicate samples of the ground glass from a single sample. Besides determining the overall analytical precision, statistical analyses identified what major contributors to the uncertainty should be targeted for future improvements.

Figures 1.1 and 1.2 summarize the results of the study. Figure 1.1 shows the composition of the glass used in the study and the relative standard deviation for the glass composition. The overall precision in terms of relative standard deviations (RSDs) was less than or equal to $5 \%$ for the major constituents except $\mathrm{K}$ and $\mathrm{Mg}$ and was less than $3 \%$ for severa 1 major constituents. Additional data showed that the RSDs for the minor constituents were $<30 \%$ except for sulfur. Figure 1.2 shows the relative sources of variance for the analysis. Instrument variations account for most of the analytical uncertainty, except for $\mathrm{Ca}, \mathrm{Al}, \mathrm{K}, \mathrm{Mg}$, and $\mathrm{Ti}$, where the preparation variations were significant. Long-term variations are the major contributor to the instrument variations. Experimenters must design future studies to account for the random long-term effects. These results are for a normalized composition. Normalizing to $100 \%$ appeared to smooth out the preparation variations for several elements. Blank corrections appear to improve the accuracy but to reduce the precision for some elements. However, the gains in accuracy seem to outweigh the costs in precision. The "other" sources of error given in 


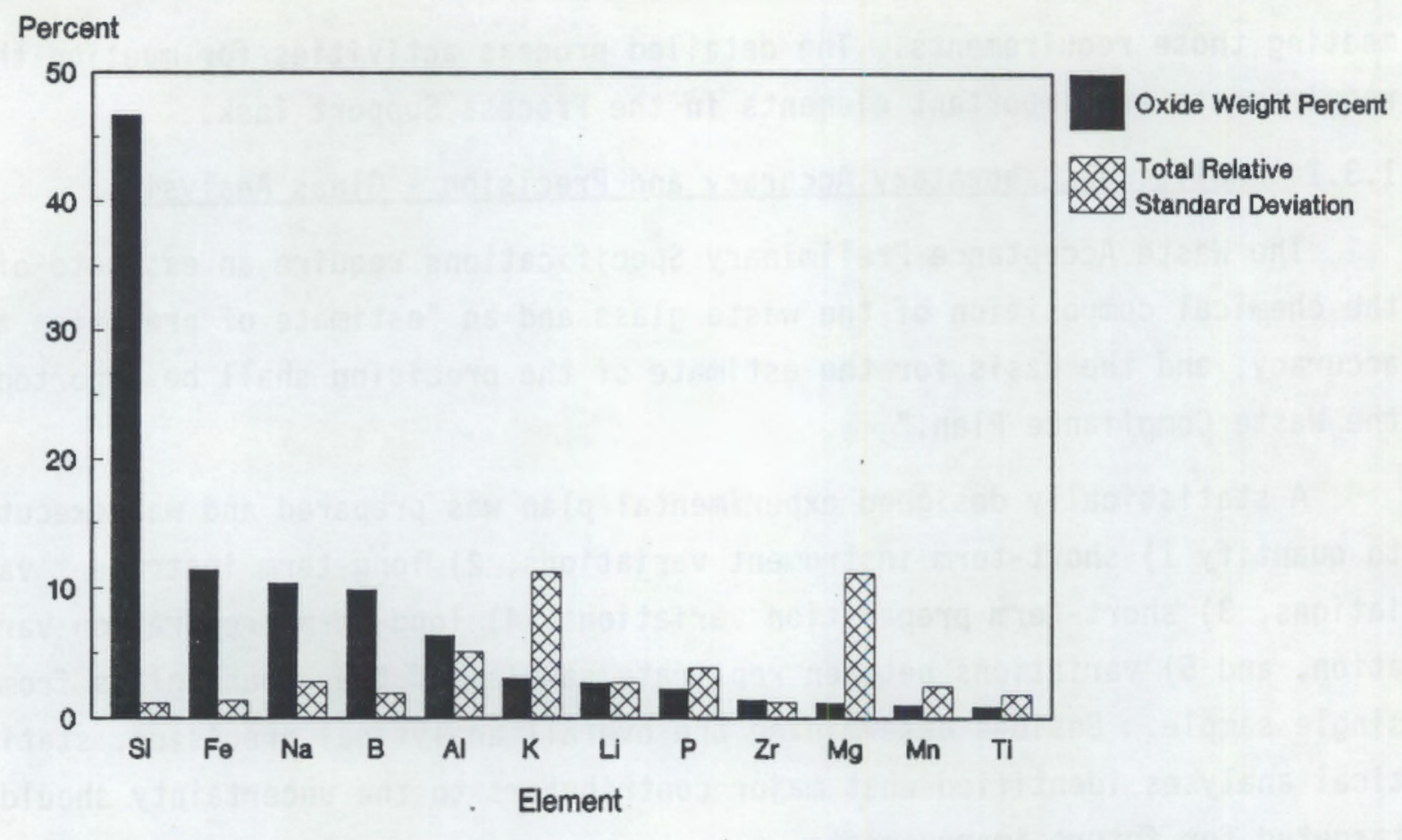

FIGURE 1.1. Uncertainty Estimates from Glass Analysis--RSD--Normalized Results

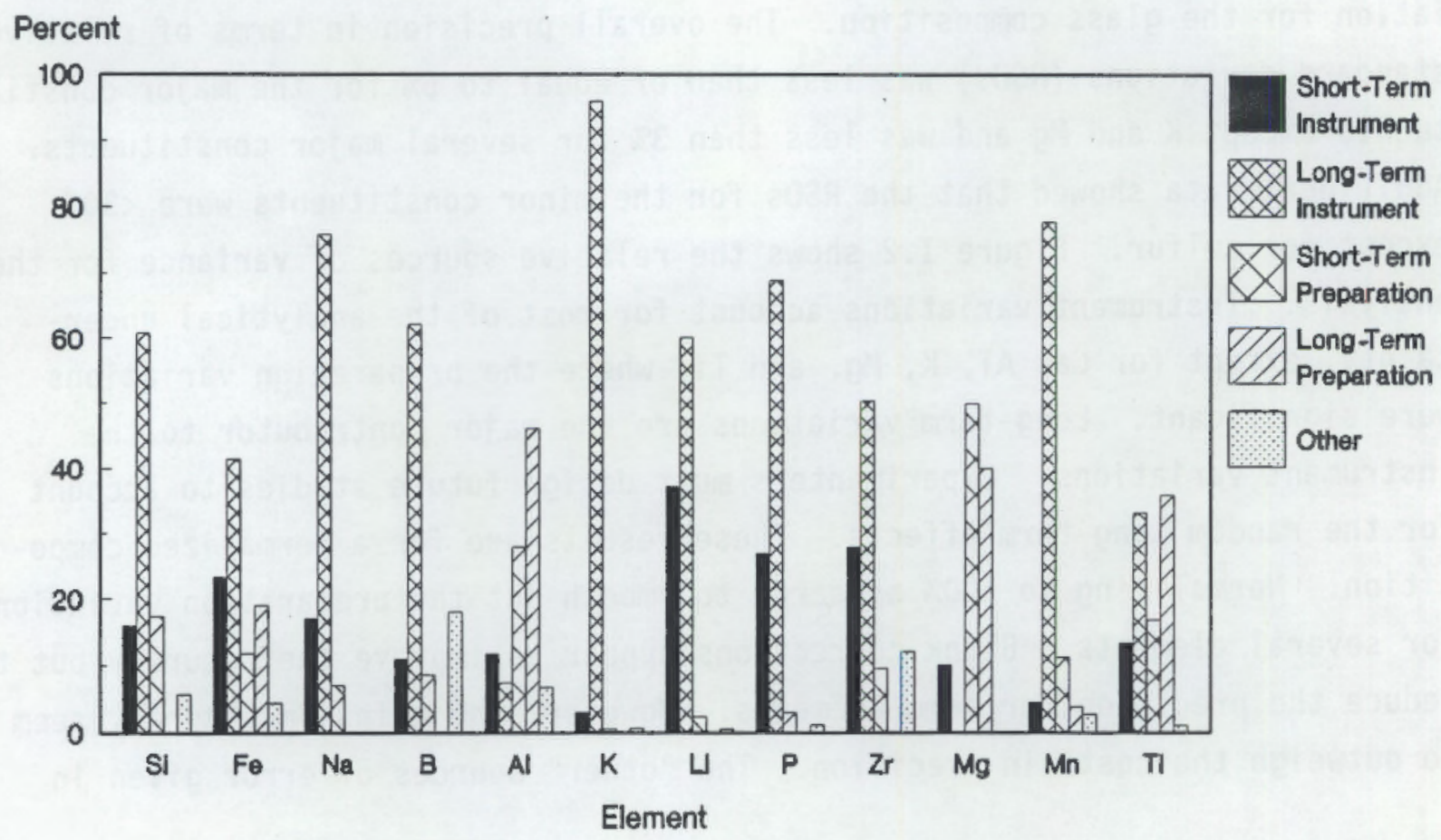

FIGURE 1.2. Uncertainty Estimates from Glass Analysis--Sources of Variance-Normalized Results 
Figure 1.2 included the homogeneity of the $M C C-W V_{205}(a)$ glass used in the testing program, which was shown to be very homogeneous.

\subsubsection{Variance for Concentrator Feed Makeup Tank, Melter Feed Hold Tank. and STurry Sampler System}

The control of composition of the final glass product depends on the ability to obtain and maintain a homogeneous composition in the feed tanks. The concentrator feed makeup tank (CFMT) receives wastes from the tank farm and secondary waste streams from the vitrification process and then concentrates them to the desired leve1. It also receives the glass-forming chemicals. The concentrated and mixed melter feed is transferred to the melter feed hold tank (MFHT) to allow the second batch of feed to be prepared while the first is fed to the melter. The MFHT homogeneity was evaluated in detai1 (Fow, Kurath, and Puisipher 1989) and was summarized in Brouns and Powell (1989). During the past year, tests were completed on the homogeneity of the CFMT and on the Hydragard slurry sampler. In general, the previous MFHT testing showed that the current agitation system in the MFHT produced a homogeneous mixture. Assuming, however, that the reference sampling method (a bottle-and-rod sampling technique) provided representative samples, the Hydragard sampling system did not obtain representative samples. After investigation of the sampling procedure, a new Hydragard operating procedure was devised to eliminate sampler bias for tests with the CFMT.

Tests of homogeneity and sampler representativeness were designed al so for the CFMT. Feed slurry samples were obtained from the CFMT during the SF-11 run and were sent to PNL for analysis of chemical composition, total solids, suspended solids, $\mathrm{pH}$, and specific gravity. The first set of samples received was obtained from the first SF-11 CFMT batch, and the second set from the second SF-11 CFMT batch. Batch 1 samples were obtained to evaluate the Hydragard sampler. Batch 2 samples were obtained primarily to characterize the CFMT homogeneity although some samples were obtained to help evaluate the Hydragard system.

(a) MCC: Materials Characterization Center. Hydragard is a registered trade name of Hines International, Inc., Hillsboro, Oregon. 


\section{Hydragard System Testing}

The data from the first CFMT batch were obtained using three sampling methods (Hydragard, recirculation pump, and dip). All samples were obtained at approximately the same vertical CFMT location although the radial location may have been different for each sampling method. Samples were also obtained using the Hydragard during transfer. Sample volumes ranged from $10 \mathrm{~mL}$ to $-30 \mathrm{~mL}$, and there were 30 samples of each type (Hydragard, pump, dip, and transfer). For clarity, the four sample types obtained during the first CFMT batch are described below:

Hydragard - Samples taken from the full CFMT using the Hydragard sampler.

Pump - Samples taken from the full CFMT using a pump in a recirculation loop.

Dip - Samples from the full CFMT using a bottle-and-rod sampling method.

Transfer - Samples taken using the Hydragard sampler during transfer of slurry from the CFMT to the MFHT.

The first sample set (SF-Il, batch 1) was analyzed to characterize the representativeness of samples taken with the Hydragard sampler. Analysis was performed by statisticaliy comparing the average compositions of the samples obtained using the different sampling methods. The statistical technique of analysis of variance was employed to compare the average compositions from the four types of samples. The assumptions of normality and homogeneity of variance appeared to be appropriate for this data set. Significant is defined as statistically significant with $95 \%$ confidence. The major conclusions from the statistical analysis follow.

- For most of the elemental constituents, there were no significant differences between the elemental concentrations obtained using the Hydragard, dip, pump, and transfer samples.

- Samples obtained using the Hydragard sampler (except those obtained during transfer) had a significantly higher boron concentration average ( $12 \%$ of $2.12 \mathrm{wt} \%$ higher) and a significantly lower neodymium concentration average $(2.5 \%$ of $839 \mathrm{ppm}$ lower) than the samples 
obtained using the other methods (see Table 1.1). The probability of a false positive difference in boron was 0.001 . The probability of a false positive difference in neodymium was 0.011 . No significant differences in boron or neodymium concentrations occurred among the dip, pump, and transfer sample types.

- The averages of total solids and suspended solids in the transfer samples marginaliy were statistically significantly greater than the solids in the other three types of samples (significant at the $90 \%$ confidence level but not at the $95 \%$ level).

TABLE 1.1. Mean Estimates for the Parameters Showing Significant Difference Among the CFMT Sample Types Taken During SF-11 from Batch 1

\begin{tabular}{|c|c|c|c|}
\hline Parameter & Sample Type & Mean & Comparjson (a) \\
\hline Total Solids & $\begin{array}{l}\text { Dip } \\
\text { Hydragard } \\
\text { Recirc. Pump } \\
\text { Transfer }\end{array}$ & $\begin{array}{l}51.58 \quad(w t \%) \\
51.55 \\
51.54 \\
51.75\end{array}$ & $\begin{array}{l}A \\
A \\
A \\
B\end{array}$ \\
\hline $\begin{array}{l}\text { Suspended } \\
\text { Solids }\end{array}$ & $\begin{array}{l}\text { Dip } \\
\text { Hydragard } \\
\text { Recirc. Pump } \\
\text { Transfer }\end{array}$ & $\begin{array}{l}27.70(w \mathrm{t} \%) \\
27.78 \\
27.79 \\
28.02\end{array}$ & $\begin{array}{l}A \\
A \\
A \\
B\end{array}(b)$ \\
\hline Boron & $\begin{array}{l}\text { Dip } \\
\text { Hydragard } \\
\text { Recirc. Pump } \\
\text { Transfer }\end{array}$ & $\begin{array}{l}2.11 \text { (wt\% metal) } \\
2.37 \\
2.10 \\
2.15\end{array}$ & $\begin{array}{l}A \\
B \\
A \\
A\end{array}$ \\
\hline Neodymium & $\begin{array}{l}\text { Dip } \\
\text { Hydragard } \\
\text { Recirc. Pump } \\
\text { Transfer }\end{array}$ & $\begin{array}{l}835.1(\mathrm{ppm} \mu \mathrm{g} / \mathrm{g}) \\
818.0 \\
839.9 \\
843.5\end{array}$ & $\begin{array}{l}A \\
B \\
A \\
A\end{array}$ \\
\hline Phosphorus & $\begin{array}{l}\text { Dip } \\
\text { Hydragard } \\
\text { Recirc. Pump } \\
\text { Transfer }\end{array}$ & $\begin{array}{l}0.771 \text { (wt\% metal) } \\
0.812 \\
0.805 \\
0.781\end{array}$ & $\begin{array}{l}A \\
B \\
B \\
A B\end{array}$ \\
\hline
\end{tabular}
(a) For a given parameter/element, the means that do not share the same letter in the comparison column are significantly different with at least $95 \%$ confidence.

(b) Marginally significantly different from the other three means for suspended solids. 
For those parameters showing significant differences among the four sample types, the mean values obtained from each sample type are given in Table 1.1. The results from these tests show that the Hydragard sampler's ability to obtain a representative sample has improved with the procedural changes but that further improvements are possible.

\section{CFMT Homogeneity}

The CFMT homogeneity could be examined by comparing the elemental concentrations derived from samples obtained at various positions within the tank. As it is difficult, however, to obtain samples at different positions within the tank without first stopping the agitation system, a different method was used. Using the Hydragard system, samples were taken from the second SF-11 CFMT batch when the tank content was at four different volumes. Samples were first obtained when the CFMT was ful1; then some of the tank content was transferred to the MFHT, and the CFMT was resampled. This transferring/sampling process continued until the CFMT level was slightly above the lower agitation blades. In addition, samples were obtained also using the recirculation pump method at two of the four tank volumes (full and third Teve1). In summary, 30 samples were obtained under each of the following configurations:

Hydra-1 - Hydragard samples when the CFMT slurry level was at $86.5 \mathrm{in}$. Hydra-2 - Hydragard samples when the CFMT slurry level was at 69 in. Hydra-3 - Hydragard samples when the CFMT slurry level was at 54 in. Hydra-4 - Hydragard samples when the CFMT slurry level was at 37 in. Recir-1 - Recirculation line samples when the CFMT slurry level was at 86.5 in.

Recir-3 - Recirculation line samples when the CFMT slurry level was at 54 in.

Two types of nonhomogeneities within the CFMT could exist. Stratification could occur such that "heavier" materials concentrated near the bottom. Besides a stratified nonhomogeneity, clumps containing certain constituents may intersperse throughout the tank. Thus some samples may contain these 
clumps while others do not. In this study, clumping nonhomogeneities would be evident from an increased standard deviation between samples taken at the same tank volume. Stratification nonhomogeneities would be manifest by differences between the average of the eTemental concentrations taken at different tank volumes.

No significant differences appeared in the sample-to-sample standard deviations between each set of tank volume samples. This suggests that the clumping nonhomogeneity does not change as the tank volume changes. But this finding does not quantify the clumping nonhomogeneity. Other studies are being conducted to characterize the sample-to-sample variations.

Chemical analyses were performed at PNL using the $x$-ray fluorescence (XRF), atomic absorption (AA), and inductively coupled plasma-atomic emission spectrophotometry (ICP-AES) methods. The statistical technique of analys is of variance was used to compare the six average elemental compositions. This comparison is one check on the occurrence of stratification nonhomogeneity. If differences are observed in the six tank volume average compositions, stratification nonhomogeneity at one or more tank volumes may be the cause. The following major results were observed:

- The samples obtained when the CFMT slurry level was at the lowest level showed concentrations significantly different from those taken at other tank levels for several elements (Si, Li, P, B, Zn, and dry percent solids). There were no significant differences, however, among the top three slurry level sample averages (see Table 1.2).

- Recirculation pump samples were statistically significantly different from Hydragard samples taken from the top three slurry levels for some elements and parameters ( $\mathrm{pH}$, suspended solids, Ce, and $B$ ).

The average concentrations or parameter values for the six sample types are shown in Table 1.2 for the elements or parameters that showed some differences among the averages. The concentrations for silicon, phosphorus, and dry weight percent were all higher at the lower tank slurry height. The boron, lithium and zinc concentrations were all lower at the lower tank slurry height. The $\mathrm{pH}$, suspended solids, and cerium values were lower in the recirculation samples than in the Hydragard samples, whereas boron was higher in 
IABLE 1.2. Mean Estimates for the Parameters Showing Significant Difference Among the CFMT Samples at Different Tank Volumes During SF-11 from Batch 2

\begin{tabular}{|c|c|c|c|c|c|c|c|}
\hline Parameter & Sample Type (a) & Mean & Comparison ${ }^{(b)}$ & Parameter & Sample Iype (a) & Mean & Comparison $^{(b)}$ \\
\hline \multirow[t]{7}{*}{$S i-X R F$} & Hydragard-86.5" & 13.77 & A & & & & \\
\hline & Hydragard-69" & 13.82 & A & $\mathrm{Zn}-\mathrm{ICP}$ & Hydragard-86.5 & 0.184 & A \\
\hline & Hydragard-54" & 13.68 & A & & Hydragard-69" & 0.185 & A \\
\hline & Hydragard-37" & 14.20 & $B$ & & Hydragard-54" & 0.184 & A \\
\hline & Recirc - 86.5" & 13.58 & A & & Hydragard-37" & 0.180 & $\mathrm{~B}$ \\
\hline & Recirc $-54 "$ & 13.42 & A & & Recirc - 86.5" & 0.186 & $A$ \\
\hline & & & & & Recirc - 54" & 0.184 & $A$ \\
\hline \multirow[t]{7}{*}{$S i-A A$} & Hydragard-86.5" & 13.77 & $A B$ & & & & \\
\hline & Hydragard-69" & 13.56 & A & Dry & Hydragard-86.5" & 52.83 & A \\
\hline & Hydragard-54" & 13.40 & A & Percent & Hydragard-69" & 52.64 & A \\
\hline & Hydragard-37" & 13.96 & 8 & & Hydragard-54" & 52.52 & $A C$ \\
\hline & Recirc - 86.5" & 13.62 & A & & Hydragard-37" & 53.12 & $\mathrm{~B}$ \\
\hline & Recirc - 54" & 13.47 & A & & Recirc - 86.5" & 52.30 & C \\
\hline & & & & & Recirc - 54" & 52.46 & $A C$ \\
\hline \multirow[t]{7}{*}{$L i-A A$} & Hydragard-86. 5" & 0.931 & A & & & & \\
\hline & Hydragard-69" & 0.935 & A & $\mathrm{pH}$ & Hydragard-86.5" & 2.91 & A \\
\hline & Hydragard $-54 "$ & 0.934 & $A$ & & Hydragard-69 & 2.90 & A \\
\hline & Hydragard-37" & 0.922 & $\mathrm{~B}$ & & Hydragard-54" & 2.92 & $A$ \\
\hline & Recirc - $86.5^{\prime \prime}$ & 0.937 & A & & Hydragard-37" & 2.94 & A \\
\hline & Recirc - 54" & 0.934 & A & & Recirc $-86.5^{\prime \prime}$ & 2.85 & B \\
\hline & & & & & Recirc $-54^{\prime \prime}$ & 2.85 & B \\
\hline \multirow[t]{7}{*}{$P$-XRF } & Hydragard-86.5" & 0.730 & A & & & & \\
\hline & Hydragard-69" & 0.733 & A & Suspended & Hydragard-86.5" & 25.87 & $A B$ \\
\hline & Hydragard-54" & 0.730 & A & Solids & Hydragard-69" & 25.95 & $A$ \\
\hline & Hydragard-37" & 0.744 & B & & Hydragard-54" & 26.09 & A \\
\hline & Recirc - $86.5^{\prime \prime}$ & 0.730 & A & & Hydragard-37" & 26.12 & A \\
\hline & Recirc - 54" & 0.730 & A & & Recirc - $86.5^{\prime \prime}$ & 25.66 & B \\
\hline & & & & & Recirc - 54" & 25.70 & B \\
\hline \multirow{7}{*}{$B-I C P$} & Hydragard-86.5" & 1.969 & A & & & & \\
\hline & Hydragard-69" & 1.989 & A & Ce-ICP & Hydragard-86.5" & 771.1 & A \\
\hline & Hydragard-54" & 1.983 & $\hat{A}$ & & Hydragard-69" & 771.5 & A \\
\hline & Hydragard-37" & 1.841 & B & & Hydragard-54" & 776.9 & A \\
\hline & Recirc - 86.5" & 2.071 & C & & Hydragard-37" & 779.8 & $\ddot{A}$ \\
\hline & Recirc - 54" & 2.056 & c & & Recirc - 86.5" & 749.8 & B \\
\hline & & & & & Recirc - 54" & 744.3 & B \\
\hline
\end{tabular}

(a) Sample Type refers to the sampler used to obta in the samples and the CFMT tank volume when the samples were obtained.

(b) For a given parameter/element, the means that do not share the same letter in the comparison column are significantly different from one another with at least $95 \%$ conf idence. 
the recirculation samples. Although statistically significant, the variations may be acceptable for process and product control.

The CFMT tank contents became nonhomogeneous at the lowest tank slurry height sampled in this study. The lowest tank slurry height is slightly above the lowest agitation blade. Adequate mixing is not obtained under current agitation speeds and configurations when the tank slurry level is at the minimum tank slurry height tested. Thus, to get a representative sample from the CFMT and obtain a homogeneous mixture, it is recommended that samples be obtained only when the CFMT slurry level is above the 37-in. level (based on this test at least $54 \mathrm{in.}$.).

\subsubsection{Removal of Sulfur from the Vitrification Process}

The sulfur level in the current wastes at West valley is higher than the vitrification process can accept. It is expected that the excess sulfur will be removed by the sludge-washing process that witl occur after the supernatant is removed from the HLW tank. This washing process should reduce the sulfur to a level a factor of three below the solubility in the glass. This work evaluated the potential means for removing sulfur from the vitrification process assuming that the current sludge removal process was not sufficiently effective.

Figure 1.3 provides a basic flow sheet for the currentiy planned sulfur removal process; on it are overlaid two potential options identified in this study for removal of sulfur from the submerged bed scrubber (SBS) condensate. Following treatment of the supernatant in Tank $8 \mathrm{D}-2$, three tanks at West Valley will contain HLW: Tank 8D-1 will contain cesium-loaded zeolite; Tank 8D-2 will contain PUREX alkaline sludge and residual supernatant; and Tank 8D4 wi 71 contain THOREX acid waste. (a) Current plans are to combine the contents of $8 \mathrm{D}-1$ and $8 \mathrm{D}-4$ into $8 \mathrm{D}-2$ and to process the waste in the vitrification facility to a borosilicate glass form.

The current WV glass 1 imit for $\mathrm{SO}_{3}$ is 0.22 wt\%. Based on the results given here and on the fact that the current WV glass is similar to a previous

(a) PUREX: plutonium-uranium extraction; THOREX: thorium extraction. 


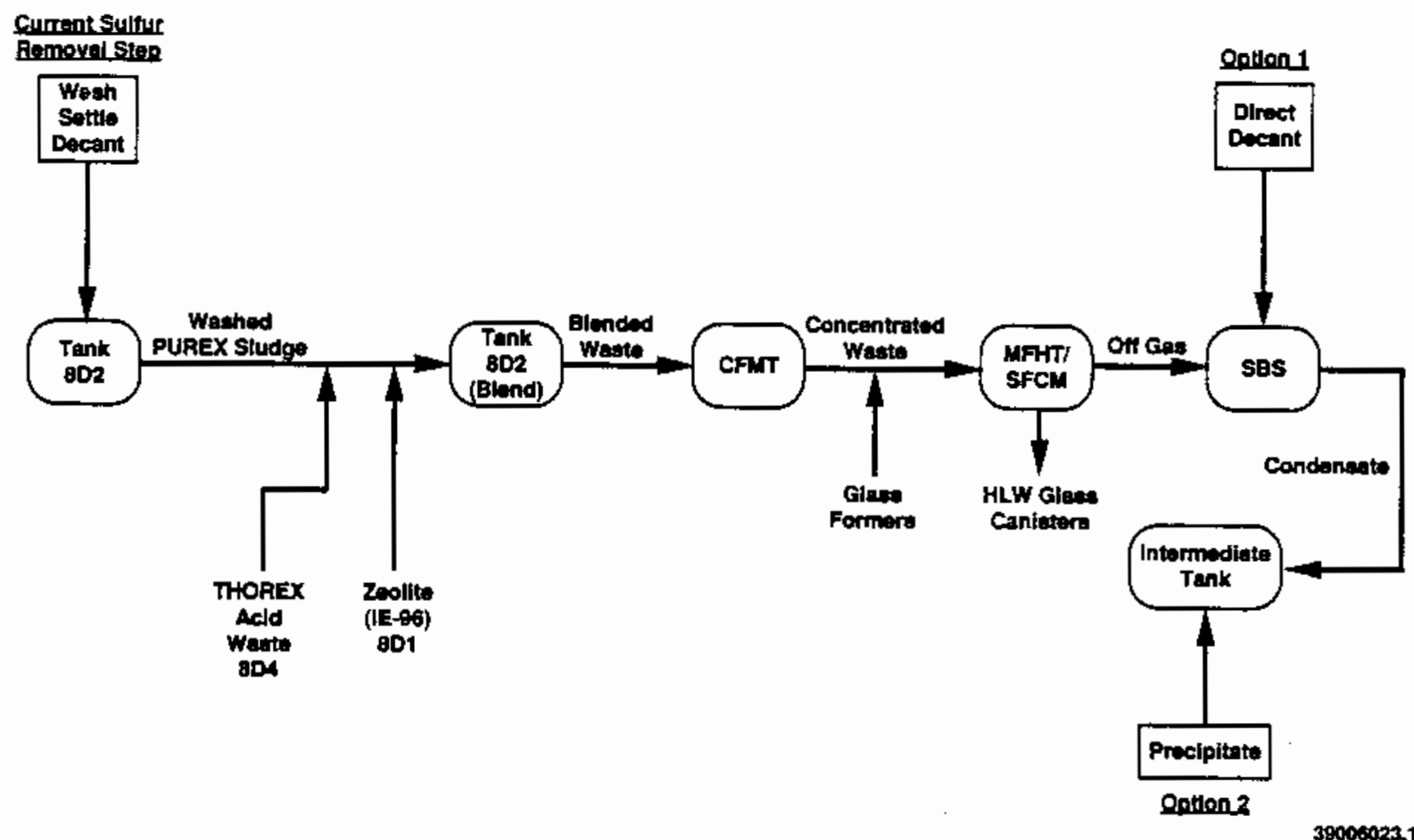

FIGURE 1.3. Process Flow Sheet and Proposed Options for Sulfur Removal. Process waste streams are not shown.

composition, WV182, for which sulfur solubility studies were performed, the level of $\mathrm{SO}_{3}$ in the waste could increase by a factor of 3 before reaching the glass sulfur solubility. Sulfur levels in excess of this value could potentially accumulate as a molten salt on the glass surface. However, the addition of reductants (such as sugar), as is now planned to control $\mathrm{Fe}^{+2} / \mathrm{Fe}^{+3}$ ratio, would also reduce $\mathrm{SO}_{4}{ }^{=}$to $\mathrm{SO}_{3}$ and allow its escape from the melter as a gas. To prevent undesirable buildup of sulfur in the process, excess sulfur should be removed from the SBS condensate before it is recycled back to the CFMT.

At plenum temperatures above $700^{\circ} \mathrm{C}$, some sulfur would leave the melter as sulfur dioxide, which has limited solubility in the SBS. scrub solution. In this case, release limits for $\mathrm{SO}_{2}$ stack emissions would require evaluation.

Options for Removing Sulfur

Two options were considered to remove sulfur from the SBS condensate before its recycle to the CFMT (refer to Figure 1.3): 1) direct decantation 
of the condensate from settled SBS solids (option 1) or 2) precipitation of the sulfur from the SBS condensate as an insoluble sulfate such as barium sulfate (option 2).

The following steps are identified for the direct decantation option:

\begin{tabular}{|c|c|}
\hline Step & Operation \\
\hline 1 & $\begin{array}{l}\text { Settle solids in SBS receiver tank or pump slurry to inter- } \\
\text { mediate tank and settle solids }\end{array}$ \\
\hline 2 & Recycle SBS solids to CFMT as feed for vitrification \\
\hline $3 \mathrm{~A}$ & $\begin{array}{l}\text { Dispose of sulfate-containing supernatant as transuranic (TRU) } \\
\text { waste }\end{array}$ \\
\hline (or 3B & Pump to zeolite column for cesium extraction \\
\hline 4 & Jet spent zeolite from extraction to Tank $80-2$ for blending \\
\hline 5) & $\begin{array}{l}\text { Dispose of sulfate-containing liquor from cesium extraction as } \\
\text { low-level waste }\end{array}$ \\
\hline
\end{tabular}

The solids in the SBS slurry would be settled either by turning off the circulators in the SBS receiver tank or by pumping the slurry to an intermediate tank for settling. The sulfate-containing supernatant would be treated in zeolite columns remaining in the supernatant treatment system (STS) or in a smaller-scale system which would require fabrication. If necessary, the supernatant could be disposed of directly in cement as a TRU waste. The SBS solids would be recycled to the CFMT for vitrification.

The following steps are identified for the precipitation option:

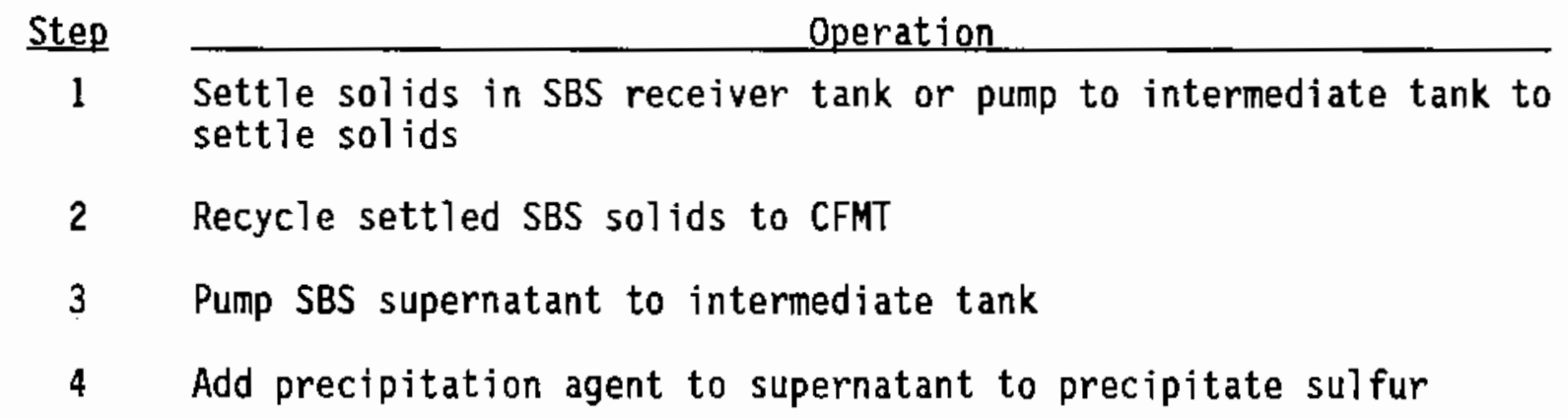


5 Separate precipitated solids from liquid either by settling or centrifugation

6 Pump liquid from precipitation step to CFMT or dispose of in cement as TRU waste

7 Wash precipitated solids

8 Pump wash supernatant to CFMT or dispose of in cement as TRU waste

9 Dispose of sulfur-containing solids as low-level waste

The SBS slurry would be allowed to settle in the SBS receiver tank by turning off the air-lift circulators. Alternatively, the SBS sTurry could be pumped to an intermediate tank for settling. The SBS supernatant would be pumped off to an intermediate tank for precipitation of the sulfur with an agent such as barium nitrate. The insoluble sulfate would then be separated from the supernatant either by settling or centrifugation. After supernatant is decanted, the solids would be washed. The supernatants from the precipitation and washing steps would be transferred to the CFMT or possibly disposed of directly in cement as a TRU waste, if necessary. The SBS solids remaining from the initial settling step would be recycled to the CFMT. The precipitated solids (containing the sulfur) would be encapsulated in cement and disposed of as low-level waste.

Table 1.3 compares the two SBS sulfur-removing options. Based on this comparison, direct decantation was recommended for the follow-on laboratory work. The benefits of direct decantation SBS sulfur removal over precipitation are: fewer process steps, no additives required, no major equipment changes, minimal additional Tiquid and solid waste generated, and the availability of preliminary laboratory support data.

\subsubsection{Mass Balance Spreadsheet}

The mass balance spreadsheets that were started in FY- 88 and reported in Brouns and Powell (1989) have been further improved, verified, and validated. They were verified by performing representative hand calculations and comparing the results to the software output data. The software was shown to 
IABLE 1.3. Comparison of Two SBS Sulfur Removal Options

\begin{tabular}{|c|c|c|}
\hline Operation & Direct Decantation & Precipitation \\
\hline $\begin{array}{l}\text { Location of } \\
\text { operation }\end{array}$ & $\begin{array}{l}\text { Potentially no additional } \\
\text { transfer steps required. }\end{array}$ & $\begin{array}{l}\text { Requires transfer to inter- } \\
\text { mediate } \operatorname{tank}(s) \text {. }\end{array}$ \\
\hline Sulfate removaT & $\begin{array}{l}\text { No additional chemicals } \\
\text { required. May require } \\
\text { intermediate tank and } \\
\text { smalT-scale STS facility. }\end{array}$ & $\begin{array}{l}\text { Requires addition of chemi- } \\
\text { cals, } 1 \text { or } 2 \text { intermediate } \\
\text { tanks, and potentially a } \\
\text { centrifuge. }\end{array}$ \\
\hline \multirow[t]{3}{*}{$\begin{array}{l}\text { Disposal of } \\
\text { supernatant }\end{array}$} & $\begin{array}{l}\text { Supernatant from SBS } \\
\text { decantation contains } \\
\text { suTfur. Treatment options: }\end{array}$ & $\begin{array}{l}\text { Supernatant derived from } \\
\text { precipitation and wash } \\
\text { steps. Treatment options: }\end{array}$ \\
\hline & $\begin{array}{l}\text { 1) Dispose in cement as TRU } \\
\text { waste }\end{array}$ & $\begin{array}{l}\text { 1) Dispose in cement as TRU } \\
\text { waste }\end{array}$ \\
\hline & $\begin{array}{l}\text { 2) Cesium extraction with } \\
\text { zeolite column: spent } \\
\text { zeolite to Tank } 80-2 \text { and } \\
\text { liquor containing the } \\
\text { sulfur to low-level waste. }\end{array}$ & 2) Recycle to CFMT. \\
\hline \multirow[t]{3}{*}{ Disposal of solids } & SBS solids recycle to CFMT. & $\begin{array}{l}\text { Two types of waste solids } \\
\text { treatment required: }\end{array}$ \\
\hline & & $\begin{array}{l}\text { 1) SBS solids recycle to } \\
\text { CFMT }\end{array}$ \\
\hline & & $\begin{array}{l}\text { 2) Solids from precipi- } \\
\text { tation step (containing } \\
\text { sulfur) disposed in cement } \\
\text { as low-level waste or as } \\
\text { TRU waste, if necessary. }\end{array}$ \\
\hline
\end{tabular}

perform all calculations within acceptable accuracy. Validation consisted of an independent review of the approach, methodology, assumptions, and mass balance structure. The software was greatly improved by combining the previous separate programs into one large program that requires extended memory to operate. Several other modifications were completed to improve the ease of following the calculations, inputting information, and modifying values to reflect the current reference compositions. The modified program provides a convenient framework to which engineering information can be added to determine effects of flow sheet changes. 


\subsubsection{Volatilization Losses During Glass Pouring}

A first-principles conservative analys is was prepared for the amount of material that can vaporize from a glass stream as it pours from the melter into the canister. Since the calculation was prepared as a bounding analysis, the analysis is expected to overestimate the material and thus provide a conservative estimate.

The analysis is based on the following description. As glass pours from the pour spout down into a canister, a surface forms that simultaneousiy releases both heat and mass. As the glass descends, its surface is cooled by radiant heat transfer but is also heated by conduction from inside the glass stream. The glass stream also narrows in diameter as it falls because its velocity increases but its volumetric flow rate remains constant. Thus the pour stream stretches as it descends, increasing the ratio of surface area to volume.

The volatile species in the glass evaporate from the surface. New mass comes to the surface via mass diffusion from within the glass stream, and it leaves the surface by diffusion through a boundary layer in the surrounding air. Cesium is considered the model volatile material.

The analysis gives the following results:

- The surface temperature of the glass as it falls into a canister is calculated to drop about $120^{\circ} \mathrm{C}$. The depth of depletion by diffusion of volatiles in the molten glass is orders of magnitude smaller than the depth of cooting by conduction of heat.

- The fraction of cesium released from the glass during the first $0.5 \mathrm{sec}$ of its fall (1.2 m) is less than $0.1 \%$.

- The calculation provided no better than order-of-magnitude estimates of the fraction of material volatilized.

\subsubsection{Effect of Melter Feed Composition on Processing Characteristics}

An analysis was performed to identify the key feed components that affect the cold-cap chemistry and, thus, the me1ter production rate. The effects of these components were then tested using laboratory techniques to determine how they can be varied to attain higher melter production rates. This work was conducted in conjunction with the production rate enhancement 
effort described in Sections 4.3 and 4.4. These sections should be referred to for data base and experimental details.

The most evident finding of this study was that although there is a large body of previous results, the characteristics of the existing data base do not support true statistical anatysis. There have been enough runs completed, but each run falls into one of three narrow windows: Defense Waste Processing Facility (DWPF) feed, Hanford Waste Vitrification Plant (HWVP) feed, or West Valley Demonstration Project (WVDP) feed. Each site has its own basic flow sheet and does not stray much from this composition. The gaps that lie between the three feed composition windows are unexplored. This is the area where further research needs to be conducted to allow more general evaluations of composition effects.

Based on the results of the statistical analysis, improved processing conditions should be achieved by the WVDP through reduction of nitrates and sugar in the melter feed. Also, the use of frit to replace the chemical glass-formers to the maximum extent possible should be investigated. Reductants in the form of oxalates, formates, and perhaps metal reductants such as silicon should be studied.

The results of the laboratory experiments confirm the statistical results: the West valley flow sheet changes to reduce nitrate and sugar concentrations in the feed should be pursued. Sugar concentrations in the feed could be minimized by using formate glass-formers as reductants. The results suggest that lower nitrates (higher hydroxide) and lower reducing agents were faster melting. They suggest also that it was beneficial to use frit and to add formates rather than nitrates.

\subsubsection{Nitrous Oxide Reduction by Selective Catalytic Reduction}

A selective catalytic reduction (SCR) system for abating process $\mathrm{NO}_{\mathrm{x}}$ emissions was evaluated at the WVDP site during both the SF-10 and SF-10A WVDP melter tests. This technology employs an $\mathrm{NH}_{3}$ reductant and a hydrogen zeolite catalyst to selectively reduce process off-gas concentrations of $\mathrm{NO}_{\mathrm{X}}$. The efficiency of SCR destruction of $\mathrm{NO}_{x}$ depends on the stoichiometric $\mathrm{NH}_{3}: \mathrm{ND}_{\mathrm{x}}$ ratio employed. The SCR effluent concentration of unreacted $\mathrm{NH}_{3}$ also depends 
on this ratio. Unreacted $\mathrm{NH}_{3}$ can combine with residual $\mathrm{NO}_{\mathrm{x}}$ to form potentially hazardous $\mathrm{NH}_{4} \mathrm{NO}_{3}$. Consequently, SCR operating control limits have to be established that will obtain the required (>91\%) $\mathrm{NO}_{\mathrm{x}}$ destruction performance while limiting $\mathrm{NH}_{4} \mathrm{NO}_{3}$ production.

Gas phase production of $\mathrm{NH}_{4} \mathrm{NO}_{3}$ was not detectable under steady-state SCR operating conditions. However, aqueous interactions with unreacted $\mathrm{NH}_{3}$ and $\mathrm{NO}_{x}$ gaseous effluent were appreciable. Aqueous interactions could account for significant process off-gas accumulations of $\mathrm{NH}_{4} \mathrm{NO}_{3}$ if off-gas system temperatures are not maintained above the dew point of the exhaust stream. Of the two mechanisms responsible for off-gas production of $\mathrm{NH}_{4} \mathrm{NO}_{3}$, aqueous effluent accumulation appears the more important and, fortunately, is the easier one to resolve. Future evaluations will be directed toward this issue in FY 1990.

\subsection{WASTE QUALIFICATION - S. 0. Bates and G. F. Piepe1}

This task supports the development of the West Valley Waste Qualification Report (WQR) that will be used to show that the West Valley product will meet the requirements established by the DOE Waste Acceptance Preliminary Specifications (WAPS) (Office of Civilian Radioactive Waste Management 1987). A major activity completed this year is the leach-testing of heat-treated

glasses. The development of literature reviews and testing $p l a n s$ for the $W Q R$ was started, but no reports were sufficiently completed in FY 1989 to be reported.

The thermal heat treatment work in this task was coordinated with work at Catholic University of America, which prepared the glass samples, and with Alfred University, which heat-treated the glasses. PNL responsibility was the leach-testing of the glass samples.

Nuclear waste glasses can devitrify at temperatures above the glass transition temperature $\left(-530^{\circ} \mathrm{C}\right)$. Devitrification is the formation of crystats in the glass, which may lead to some loss of chemical durability. The selected method for examining the devitrification kinetics invoives heattreating the specimens under isothermal conditions so that any thermally activated transformations can be identified and characterized. The efforts were focused on the reference West Valley waste composition WVCM-59 glass. The 
heat treatments and times were selected to bracket the time and exposure that the glass would experience in its cooldown after transfer from the melter into the canister. The temperatures selected were $600,700,800$, and $900^{\circ} \mathrm{C}$, and the holding times were 3, 24, and $96 \mathrm{hr}$.

The leach-testing was conducted by the MCC-1 and MCC-3 leach test methods (Mendel DOE/TIC; Mendel 1986). Leachates were analyzed for Si, Al, B, $\mathrm{Ca}, \mathrm{Fe}, \mathrm{K}, \mathrm{Li}, \mathrm{Mo}, \mathrm{Na}, \mathrm{P}, \mathrm{Cs}$, Th, $\mathrm{U}$, and $\mathrm{pH}$; the most leachable element is boron. The MCC-1 data for each of the glasses and heat treatments are shown in Figures 1.4 and 1.5 .

The results from both the MCC-1 and MCC-3 testing indicate that the heat treatments affected glass durability, although it is not a large effect. The most extreme decreases in durability (based on boron release) due to the heat treatments were observed at the $600^{\circ} \mathrm{C} 96-\mathrm{hr}$ condition and the $700^{\circ} \mathrm{C} 24-$ and 96-hr conditions. The $600^{\circ} \mathrm{C}, 96-\mathrm{hr}$ condition has a decrease in durability of $50 \%$ for MCC-1 testing and a $35 \%$ decrease in MCC-3 testing. Heat treatment at greater than $800^{\circ} \mathrm{C}$ had no significant effect on the glass durability.

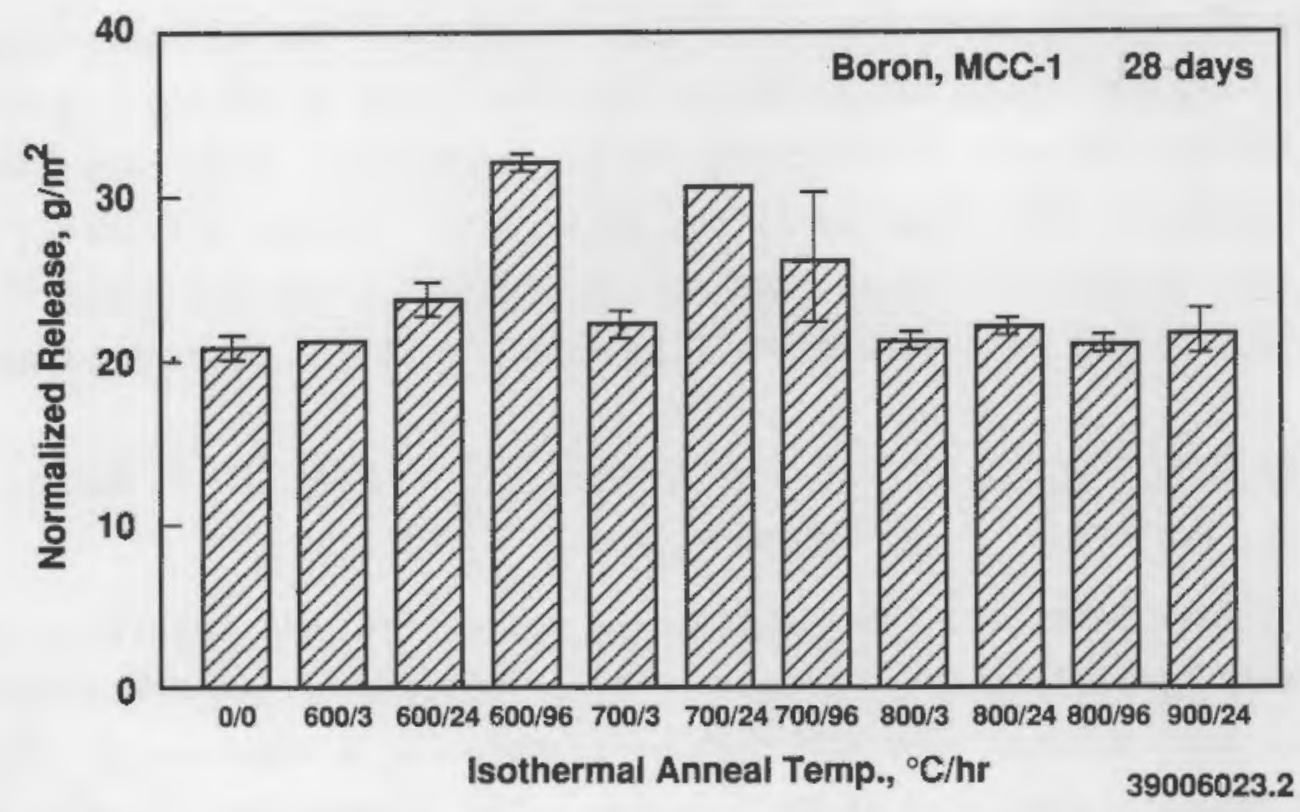

FIGURE 1.4. Comparison of Boron Average Normalized Releases from Isothermally Heat-Treated Glasses: MCC-1, 28 days, Deaerated Deionized Water, $10 \mathrm{~m}^{-1}$. Error bars represent \pm 2 standard deviation. 


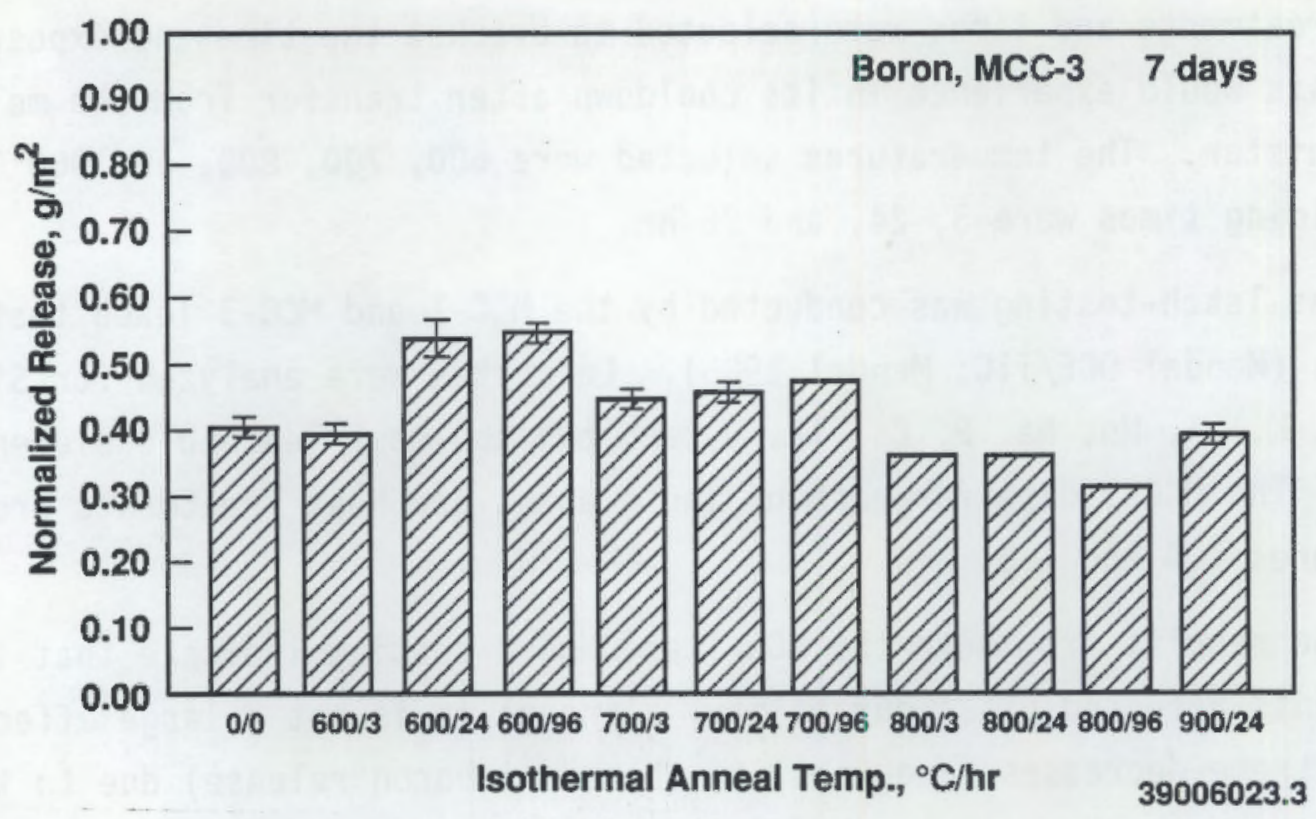

FIGURE 1.5. Comparison of Boron Average Normalized Releases from Isothermally Heat-Treated Glasses: MCC-3, 7 days, Deaerated Deionized Water, $2000 \mathrm{~m}^{-1}$. Error bars represent \pm 2 standard deviation.

These effects on durability cannot be attributed solely to a relative increase of crystallinity caused by heat treatment. Not a11 glasses with increased crystallinity had corresponding magnitudes of durability decrease. Phases formed that may be affecting the glass most are acmite and calcium phosphate phases identified by Alfred University. Alfred University also identified formation of spinel and cerium, thorium oxide and identified that the maximum volume of crystals was $2.5 \%$ with the $700^{\circ} \mathrm{C}, 96-\mathrm{hr}$ treatment.

\subsection{IANK FARM PROCESS SUPPORT - W. A. Ross, L. A. Bray, D. E. Kurath,}

R. E. Westerman, M. R. Telander, and S. G. Pitman

This task comprises those activities associated with supporting West Valley with respect to the storage and preprocessing of the HLW currently stored at West Valley. The HLW that is composed of a supernatant and a sludge is in storage in tank $8 \mathrm{D}-2$ at West Valley. The supernatant is being processed though the supernatant treatment system (STS) to remove the radioactive cesium. The remaining supernatant is then processed through the LLW treatment system and solidified as cement as LLW. During FY 1989 this task helped WVNS 
in resolving a processing problem with the STS and looked at corrosion of the 8D-1 tank, where the cesium removed from the supernatant is stored on the zeolite ion exchange material.

\subsubsection{Support for STS Operations}

The STS has four ion exchange columns. The first column is loaded until breakthrough occurs; then it is dumped and reloaded with fresh zeolite and placed in service as the fourth column. The previous second column then becomes the lead column until it is loaded, and the process continues with successive replacement of the lead column and fresh zeolite in the last column. During STS processing operations the dump valve on one ion exchange column became defective and the zeolite could not be dumped. PNL was asked to look at various alternatives and provided recommendations to relieve the problem. The method recommended was to remove sufficient zeolite with a flushout "J" tube to be below the distribution plate. This would reduce the heel to less than $7 \mathrm{in}$. (about $220 \mathrm{lb}$ ). Calculations and experiments were performed to show that a uniformly thick 2-in. layer of fresh zeolite on top of the heel would be sufficient to prevent recontamination of the decontaminated supernatant when the defective column was used last in series. The experiments indicated that it would take 14 days for sufficient cesium to diffuse through the 2-in.-thick stagnant water zeolite layer before the heel could recontaminate the supernatant. This allowed sufficient time to finish loading the first column.

A second alternative investigated was the use of chemicals to elute the ${ }^{137} \mathrm{Cs}$ from the heel in the ion exchange column. A series of various strength solutions of sodium, potassium, and nonradioactive cesium were tested. The natural cesium salts appear to be the most effective in removing radioactive cesium from the loaded zeolite.

A paper was also prepared (Kurath et a1. 1989) that compared the predictions of the STS performance from laboratory-scale experiments with the results obtained during production. 


\subsubsection{Tank Corrosion Testing}

PNL has investigated the potential susceptibility of WVNS tank 8D-1 to corrosive attack by the cesium-containing zeolites and associated solutions currently being stored in the tank. The solution in the tanks is maintained at a high $\mathrm{pH}$ to minimize corrosion. The study involved exposing mild steel specimens, in U-bend (stressed) configuration, to four different environmental conditions that could be relevant to the actual tank environment. The major test variables were temperature $\left(65^{\circ} \mathrm{C}\right.$ and $\left.90^{\circ} \mathrm{C}\right)$, irradiation intensity $\left(\sim 1 \times 10^{5} \mathrm{rad} / \mathrm{hr}\right.$ and none), and nitrite ion concentration (300 ppm and $600 \mathrm{ppm})$. The test objective was primarily to determine whether there is any suggestion of stress corrosion cracking. In addition, the rates of pitting and general corrosion of the mild steel specimens were estimated.

The mild steel was obtained from steel sections that had been cut from the top of tank 8D-2 in order to install the sludge pumps for use later in processing the waste. Specimens were located in three different conditions for each test, which lasted either 3 or 6 weeks. The first environment is vapor exposure only, the second is immersion in supernatant only, and the third was exposure under the zeolite.

The general corrosion data from the tests are shown in Figure 1.6. As can be noted, Tests 2 and 3 show the highest uniform corrosion rates. The specimens did not show any stress corrosion cracking, a major finding of the test. The data indicate, as expected, that radiation may be an important factor. The tests indicated also that pitting may be of more concern, with higher than desired rates observed in Tests 2 and 3 . One possible cause of the pitting is that the zeolite reacts with the hydroxide in solution and reduces its passivation effects. These data are to be compared with in-tank specimens under test by WVNS.

\subsection{REFERENCES}

Bray, L. A. 1988. Development of a Chemical Process Using Nitric AcidCerium(IV) for Decontamination of High-Level Waste Canisters. PNL-6567. Pacific Northwest Laboratory, Richland, Washington. 


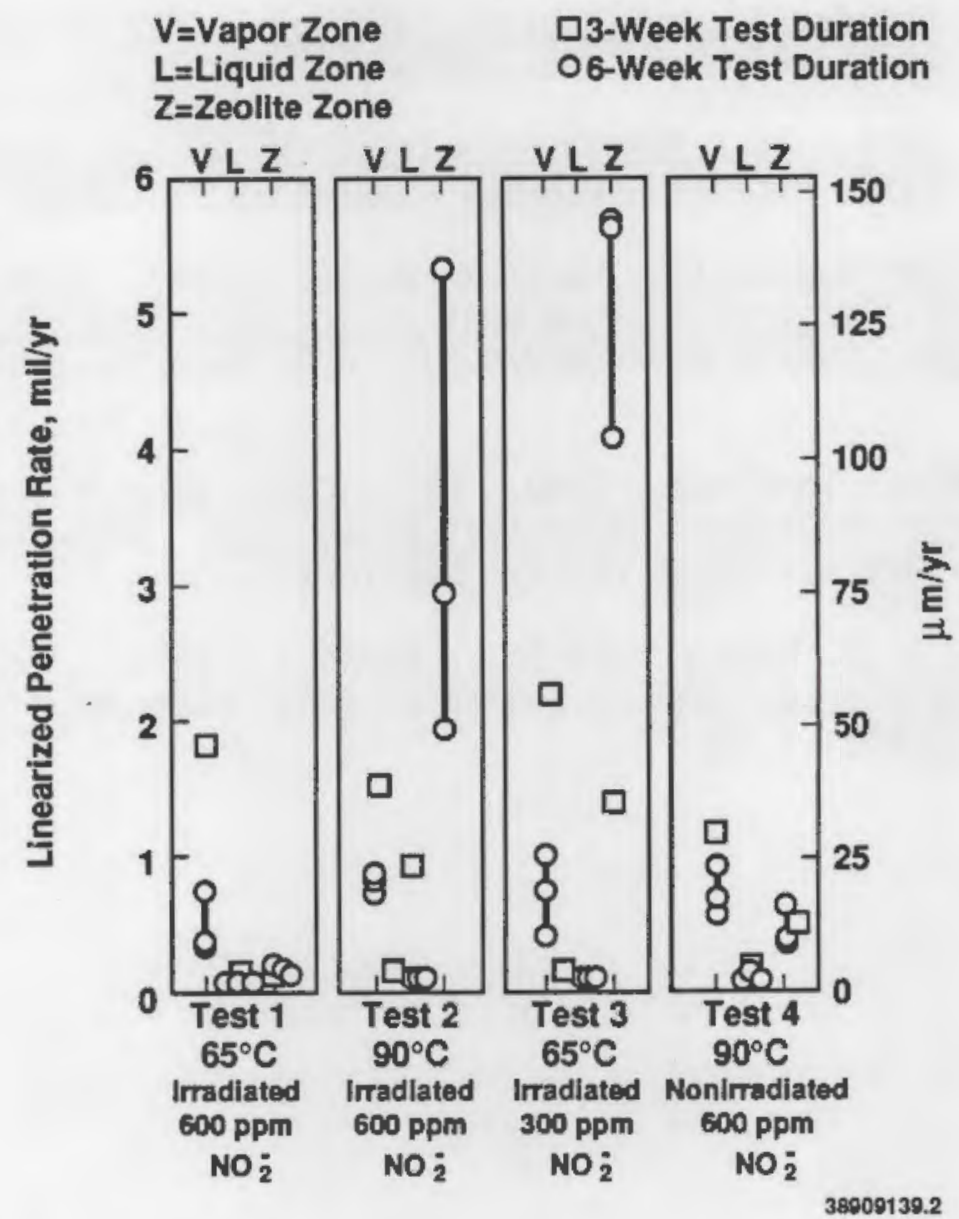

FIGURE 1.6. Corrosion Data. Uniform penetration is assumed in all cases.

Bray, L. A., and J. M. Seay. 1988. "Development and Design Application of Cerium (IV) Decontamination Process." Proceedings Spectrum ' 88 Nuclear and Hazardous Waste Management International Topical Meeting, p. 284, Pasco, Washington.

Brouns, R. A., and J. A. Powell. 1989. Nuclear Waste Treatment Program Annual Report for FY 1988. PNL-7131, Pacific Northwest Laboratory, Richland, Washington.

Fow, C. L., D. E. Kurath, and B. A. Pulsipher. 1989. Evaluation of the Mixing System for the West Valley Melter Feed Hold Tank. PNL-6724. Pacific Northwest Laboratory, Richland, Washington.

Kurath, D. E., L. A. Bray, W. A. Ross, and D. K. Ploetz. 1989. "Correlation of Laboratory Testing and Actual Dperations for the West Valley Supernatant Treatment System." Proceedings of the Fourth International Symposium on Ceramics in Nuclear Waste Management, American Ceramic Society. 
Mendel, J. E. Nuclear Waste Materials Handbook. DOE/TIC-11400. Pacific Northwest Laboratory, Richland, Washington.

Mende1, J. E. 1986. Test Methods Submitted for Nuclear Waste Materials Handbook. PNL-3990, Pacific Northwest Laboratory, Richland, Washington.

Office of Civilian Radioactive Waste Management. 1987. Waste Acceptance Preliminary Specifications for the West Valley Demonstration Project HighLevel Waste Form. DOE/RW-0136 (OGR/b-9). U.S. Department of Energy, Washington, DC.

West Valley Nuclear Services. 1988. Waste Compliance Plan for the West Valley Demonstration Project High-Level Waste Form. WVNS-WCP-001. West Valley Nuclear Services, West Valley, New York.

Wichman, K. R., A. G. Hooper, and J. L. Mershon. 1979. "Local Stresses in Spherical and Cylindrical Shells Due to External Loadings." Welding Research Council Bulletin Number 107. 


\subsection{FRG CANISTER LOAOOUT AND TRANSPORTATION}

L. K. Holton - Manager

\subsection{OBJECTIVE}

The objective of this task is to characterize and load 32 isotopic heat and radiation sources (canisters) containing borosilicate glass for shipment to West Germany.

\subsection{INTRODUCTION}

Because the liquid-fed ceramic melter (LFCM) is widely accepted as the reference waste vitrification process in the U.S., OOE requested that PNL design, construct and operate a prototypical radioactive pilot-scale waste solidification facility employing the LFCM process. Pilot-scale radioactive testing is used to validate the design and operating data being applied to the three production-scale projects. The RLFCM is also providing needed documentation of design, data, and operating experience for use by architectengineers involved with future commercial waste treatment facilities. The RLFCM equipment was installed in FY 1984 (Burkholder and Rusin 1985) and underwent shakedown testing in FY 1985 using higher levels of activity in each test. In FY 1986, preparation of isotopic heat and radiation sources for the Federal Republic of Germany (FRG) began. These sources using ${ }^{90} \mathrm{Sr}$ and ${ }^{137} \mathrm{Cs}$ as the active isotopes in borosilicate glass are to be employed as part of a repository testing program in the Asse Salt Mine located in northeastern West Germany.

Decontamination, characterization and storage of the canisters of waste glass have required the use of hot-cell space because the $\mathrm{glass}$ contains large quantities of radioactivity. The 324 Building's A Cell, adjacent to B Cell where the RLFCM is located, was selected for this work. Cleanout of obsolete equipment and decontamination and renovation of $\mathrm{A}$ Cell have made the needed space available. Extensive radionuclide decontamination of the cell has been necessary to ensure that canisters decontaminated for shipment are not recontaminated during interim storage. 
The 32 isotopic heat and radiation sources (canisters) were produced using the remotely operated RLFCM. (a) The canisters were filled with a borosilicate glass in PNL's radiochemical engineering cell complex in the 324 Building, where the RLFCM, together with its supporting equipment, was located in the largest of four hot cells. This equipment included the feed makeup and feed system, the canister handling and storage systems, and the off-gas treatment system of the RLFCM. After all canisters had been filled, the lids were welded on using a remotely operated welding system, and the canisters were then decontaminated by electropolishing. The canisters were physically characterized using a series of nondestructive tests and measurements.

After the welding of the canister lid to the canister, it was passed into an air lock between the hot cell containing the vitrification equipment and the cell containing the decontamination equipment. In the air lock the integrity of the lid weld was verified using a helium leak-detection system and the canister surface exposure rate was measured. The remaining physical measurements were performed in the decontamination cell before the canisters were $\mathrm{placed}$ in a water-cooled storage rack, where they will remain until shipment to the FRG.

\subsection{PROGRESS IN FY 1989 - Y. B. Katayama}

While the FRG canisters are awaiting approval for shipping, the primary technical work has been preparation for their shipment.

A cargo container with two GNS-12 casks and their impact limiters mounted inside was received from West Germany. The shipping casks, shipping container, and handling equipment were all tested during the past year. A Functional Test Plan was written and approved for verifying the dimensions of the received equipment, for evaluating the ease of remote handling, and for learning the operational requirements of the sponsor-supplied cask-sealing and leak-check system.

(a) For accounts of earlier work in this program, the reader is referred to prior annual reports in this series: PNL-7131, -6686 , and -6325 . 
The leak test equipment was assembled, and calibrations consistent with the Quality Assurance Impact Level II were made of the sponsor-supplied equipment. The pressure sensor and indicator supplied by the sponsor have pressure ranges from 0 to $2000 \mathrm{mb}$, and the GNS test specification PV 306/2E requires operation at $2000 \mathrm{mb}$, the top end of the test equipment. Resolution of the meter readings is expected to limit the accuracy of the leak rate calculations. Although the upper impact limiters were found difficult to remove because bolthole tolerance would not allow any uneven lifting of the 1 imiters, they are contact-removed and thus delays in their removal would be acceptable. As identical spare parts may not be available within the continental United States, they should be supplied by the sponsor.

The functional testing also provided an opportune time to schedule a hands-on training session for hot-cell technicians in the loading, cask closure, and leak checking of the GNS-12 cask. A critical point in loading the FRG canisters into the cask may be the centering of the canister directly above the opening of the aluminum basket in the GNS-12 cask, especially if the canister is swinging on the crane. The canister may need to be carefully touched to the basket to stop the swing but not hard enough to dislodge the canister from its lifting yoke. 



\subsection{GREATER-THAN-CLASS-C LOW-LEVEL WASTE}

J. H. Jarrett - Manager

\subsection{OBJECTIVES}

The objectives of the PNL Greater-than-Class-C (GTCC) Low-Level Waste (LLW) Program are to evaluate options for waste packaging, transportation, treatment and disposal; to develop an approach toward disposal fee determination and administration; and to provide treatment technology development and demonstration to support the overall GTCC LLW Program.

\subsection{BACKGROUND}

Public Law 99-240, "The Low-Level Radioactive Waste Policy Amendments Act of 1985," signed into law January 15, 1986, gave DOE the responsibility for disposal of Greater-than-Class-C (GTCC) low-level waste (LLW) as defined by Title 10 CFR 61.55 .

The law required also that DOE submit to Congress a report on findings and recommendations for ensuring safe management and disposal of this waste. DOE's report (DOE/NE-0077) was issued in February 1987. The DOE Strategic P1an for GTCC LLW (DOE/LLW-79T, Revision 2) was issued in February 1989. It outlined a strategy for accepting limited quantities of waste starting in mid-1989, providing for dedicated storage by January 1, 1995, and beginning disposal in an NRC-1icensed facility by 2010.

It is estimated that there are $60 \mathrm{~m}^{3}$ of GTCC LLW in storage at power reactor sites, fuel-testing laboratories, and sealed source manufacturers' sites. The waste generation rate through 1995 has not been estimated, but will probably be between 20 and $50 \mathrm{~m}^{3}$ per year. The total projected volume by the year 2035 is about $20,000 \mathrm{~m}^{3}$.

\subsection{PROGRAM COMPONENTS}

The PNL Greater-than-Class-C Low-Level Waste (GTCC LLW) Program was initiated in FY 1989, providing a key contribution to the national GTCC Program, 
managed for DOE by EG\&G-Idaho. The national program consists of the following tasks, with PNL responsible for Tasks 3, 6, 7 and 8 .

Task 1 GTCC Program Support Activities/Project Management

Task 2 Waste Characterization and Volume Projection

Task 3 Packaging/Transportation - R. I. Smith, Task Leader

Task 4 Interim Storage

Task 5 Dedicated Storage

Task 6 Disposal - D. A. Lamar, Task Leader

Task 7 Fee Specifications - L. L. Clark, Task Leader

Task 8 Waste Treatment - D. E. Kurath, Task Leader

Successful completion of all the tasks will result in fulfilling the requirements $p l a c e d$ on DOE by Congress while ensuring safe storage and disposal of civilian GTCC LLW at a minimum cost.

\subsection{PROGRESS IN FY 1989}

In FY 1989 PNL developed an approach to its assigned tasks and prepared the following draft reports:

- Draft Packaging and Transportation Alternatives. This draft identifies and evaluates alternatives for packaging and transporting GTCC wastes. Cost estimates are made for packaging and transport, and recommendations are made for the preferred approach.

- Approach and Expanded Outline of Disposal Options Analysis. The options analysis will include evaluation of two generic sites (arid and humid); use of selected release, flow, transport and dose models; use of selected exposure scenarios (disposal operations; post-disposa1--intruder and nonintruder; ground water and surface water transport; and air transport); and evaluation of several disposal systems from deep geologic through shallow land burial.

- Draft Fee Methodology. A fee calculation method for management of GTCC LLW is described, similar to the High-Level Waste fee determination using the FEe ANalysis (FEAN) code, except for the use of different cost centers, a modified rationale for assessing disposal costs, and other minor differences.

- Preliminary Fee Schedule and Methodology. This report addresses comments on the draft fee methodology report and uses the FEAN model 
to give a preliminary estimate of the GTCC fee, using assumed estimates for various cost elements. The report suggests that the GTCC fee be assessed based on waste volume, radiation level, and the treatment required.

- Treatment Options Analysis Progress Report. The progress report outlines the treatment options analysis report and discusses each report section. Included is a discussion on GTCC waste characteristics, treatment technologies and options (size reduction, compaction, incineration, decontamination, and waste form preparation).

An approach to completing and issuing these reports in FY 1990 and FY 1991 was agreed upon, incorporating comments from EG\&G-Idaho and DOE. PNL's FY 1990 tasks remain the same, and details of FY 1990 activities have been defined. 



\subsection{PRODUCTION RATE ENHANCEMENT}

C. C. Chapman - Manager

\section{$4: 1 \quad$ OBJECTIVE}

The objective of the Production Rate Enhancement Task is to identify which factors affect the differences in vitrification rate in ceramic melters and to devise practical, plant-relevant proposals for increasing production rates.

\subsection{INTRODUCTION}

Large amounts of high-level nuclear waste have been produced in the U.S. and are currently being stored temporarily in underground tanks. The waste originated from defense-related reprocessing of military fuels and from commercial power reactors. Currently, defense high-level waste (HLW) is stored at the Savannah River Site in South Carolina, Hanford Reservation in Washington State, and the Idaho National Engineering Laboratory. Commercial HLW is stored at the West Valley Site in New York State. The waste at these sites will eventually be converted to a stable product form and permanently stored in underground facilities. The U.S. has chosen vitrification as the reference process to immobilize the waste in a borosilicate glass matrix resistant to radioactive damage and to leaching. Vitrification plants are currently under construction at Savannah River and West Valley, and a plant is in the design stages at Hanford.

The reference vitrification process chosen by the U.S. mixes the HLW with glass-formers in a slurry. The slurry is fed to a joule-heated ceramic melter, where the water is evaporated and the solids are transformed into a molten glass. The glass is poured into stainless steel canisters and allowed to cool. The canisters are then sealed, decontaminated and temporarily stored until they can be shipped to a permanent underground storage facility.

In nonradioactive testing at the three sites, the physical and chemical makeup of the vitrification process has been designed to optimize production rate while achieving a durable glass product. Because vitrification involves a complex group of reactions and transformations, the process is still poorly 
understood. The specific throughput capacity for converting the waste slurry feed into a molten glass in a joule-heated ceramic melter typically ranges between 40 and $60 \mathrm{~L}$ slurry $/ \mathrm{hr}-\mathrm{m}^{2}$ of melter surface area and 20 to $30 \mathrm{~kg} \mathrm{glass} /$ $\mathrm{hr}-\mathrm{m}^{2}$. This rate is not consistently reproducible, nor is the reproducibility of the transformation process well understood. Results have varied broadly with the same melter and apparently very similar feeds. The implications for production cost can be significant. Thus in FY 1989 PNL began a study to enhance the vitrification rate of ceramic melters.

\subsection{DATA BASE ANALYSIS - M. L. Elliott and B. A. Pulsipher}

The purpose of this activity was to identify the key feed components that affect the cold-cap chemistry and, thus, the melter production rate. The effects of these components were then tested using laboratory techniques to determine how they can be varied to attain higher melter production rates. To identify the key components, a11 available melter run data were collected into a library. The key independent variables were identified that were felt to influence glass production rate. The data library was then condensed into a computer data base containing the independent variables and the dependent variables from each melter run. The data base was then manipulated to normalize all data into a similar set of units. Statistical analysis was performed on the data base to determine the relative effects of each independent variable on melter production rate.

The complete data base library file contained the data from 39 melter runs. A secondary result of this activity was simply the compilation of many melter run summaries into a format that permits comprehensive analysis. The most evident finding of this study was that although there is a large body of previous results, the characteristics of the existing data base do not support true statistical analysis. There have been enough runs completed, but each run falls into one of three narrow windows: Defense Waste Processing Facility (DWPF) feed, Hanford Waste Vitrification Plant (HWVP) feed, or West Valley Demonstration Project (WVDP) feed. Each site has its own basic flow sheet and does not stray much from this composition. The gaps that lie between the 
three feed composition windows are unexplored. This is the area where further research needs to be conducted to allow more general evaluations of composition effects.

Based on the results of the statistical analysis, improved processing conditions should be achieved by the WVDP through reduction of nitrates and sugars in the melter feed. Also, the use of frit to replace the chemical glass-formers to the maximum extent should be investigated. Reductants in the form of oxalates, formates, and perhaps metals such as silicon should be studied.

Finally, an additional feed preparation step such as formic acid treatment of the melter feed may be beneficial. Experience with formic acid treatment of DWPF and HWVP feeds has shown improved process behavior. This alternative, however, would require additional process equipment for West valley. Therefore its possible use should be considered only after evaluating and rejecting the previously discussed process modifications.

\subsection{LABORATORY-SCALE EXPERIMENTS - D. D. Yasuda and M. L. El1 iott}

Following the data base analysis, a set of laboratory experiments was conducted to obtain semiquantitative data on melter feed composition variables that may significantly affect the throughput rate of the liquid-fed ceramic melters. The waste composition was based on the West Valley waste composition tested at West Valley during the SF-10C melter test. It was anticipated that important feed composition variables would include: nitrate concentration, sugar concentration, the use of frit versus glass-forming chemicals, and the use of formate glass-forming chemicals. The testing matrix is given in Table 4.1.

The laboratory tests were performed with crucibles of glass in an electrically heated furnace (see Figure 4.1). The Denver Fire Clay (DFC) crucibles initially contained $40 \mathrm{~g}$ of glass and were preheated to $1120^{\circ} \mathrm{C}$. Fifteen milliliters of the prepared feed were then added to the crucible over a 1-min period and allowed to react for a second minute, after which $15 \mathrm{~mL}$ of additional feed were added to the crucible. After a predetermined period, the 
TABLE 4.1. Feed Matrix for Laboratory Testing

\begin{tabular}{|c|c|c|c|c|c|c|}
\hline Feed No. & $\begin{array}{l}\text { Nitrate } \\
\text { Level }\end{array}$ & Sugar & Formates & $\begin{array}{l}\mathrm{Fe}^{+2} / \mathrm{Fe}^{+3} \\
\text { Analysis }\end{array}$ & $\begin{array}{c}\text { Glass- } \\
\text { Formers, \% }\end{array}$ & Frit, $\%$ \\
\hline 1 & Min & No & No & No & 100 & 0 \\
\hline 2 & Min & Yes & No & Yes & 100 & 0 \\
\hline 3 & Min & No & Yes & Yes & 100 & 0 \\
\hline 4 & Min & Yes & Yes & Yes & 100 & 0 \\
\hline 5 & Norm & No & No & No & 100 & 0 \\
\hline 6 & Norm & Yes & No & Yes & 100 & 0 \\
\hline 7 & Norm & No & Yes & Yes & 100 & 0 \\
\hline 8 & Norm & Yes & Yes & Yes & 100 & 0 \\
\hline 9 & $\operatorname{Max}$ & No & No & No & 100 & 0 \\
\hline 10 & Min & Yes & No & Yes & 0 & 100 \\
\hline 11 & Norm & Yes & No & Yes & 0 & 100 \\
\hline 12 & Min & Yes & No & Yes & 25 & 75 \\
\hline 13 & Norm & Yes & No & Yes & 25 & 75 \\
\hline
\end{tabular}

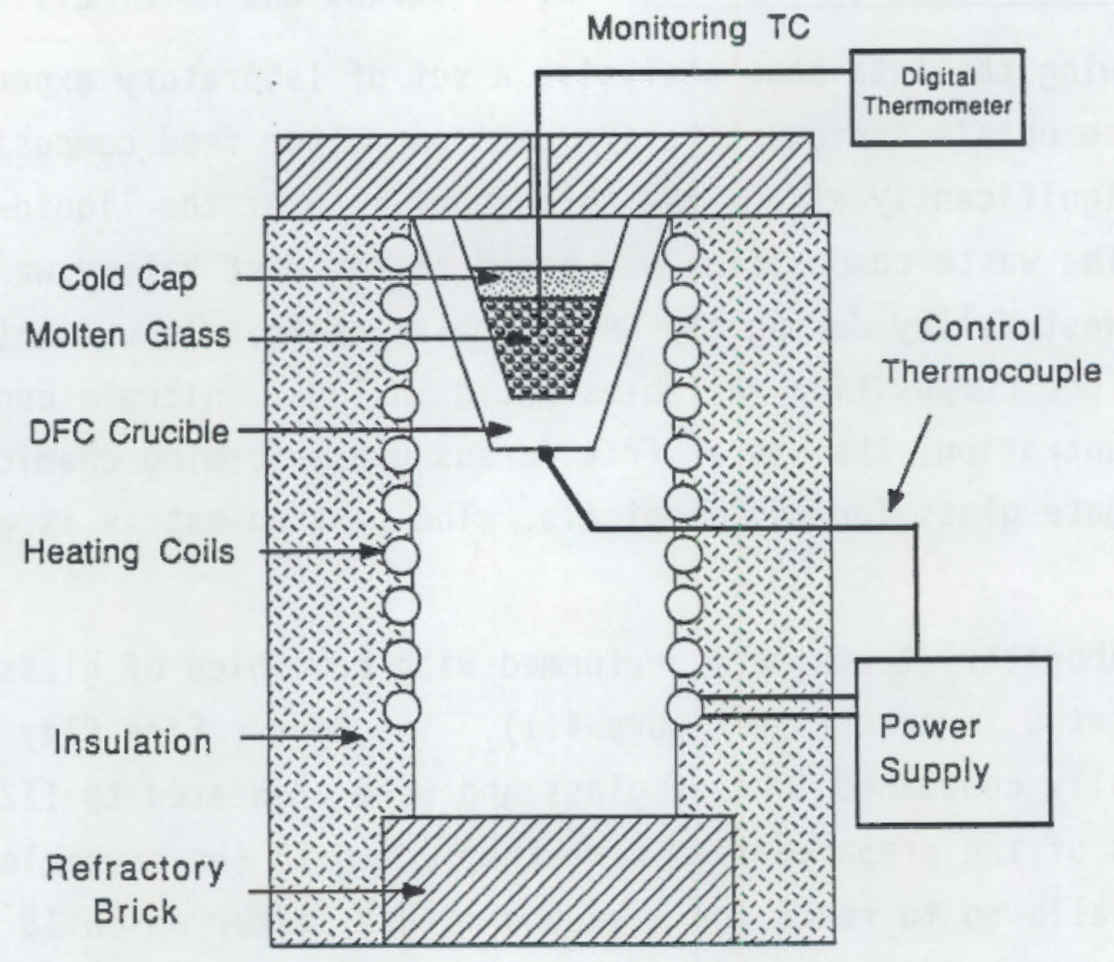

FIGURE 4.1. Laboratory Test Arrangements 
crucible was sectioned in half vertically and the volume of remaining cold cap measured with a planimeter. Four to seven crucible tests were performed for each type of feed, with different holding periods at temperature. The residual cold-cap cross-sectional area was then plotted as a function of time as in Figures 4.2 through 4.4 , and the time was extrapolated to zero cold caps, i.e., the time to react and melt into the glass.

Test results indicated that feeds containing formates or frit (Nos. 3 , 7,8 , and 10 through 13) melt fastest (see Figures 4.2 and 4.3 ). The data scatter in the tests makes ranking them statistically impossible, as seen in the wide $90 \%$ confidence intervals in Figure 4.4 . Most of this uncertainty was due to foaming. The faster melting feeds had better confidence intervals. Minimal foaming was observed with the frit feeds. Together these results support the contention that frit and formates have the largest positive effect on slurry processing.

Feeds 2 and 6, 7, and 8, shown in Figures 4.2 and 4.5, appear to belong in the second group of feeds with intermediate processing rates. Foaming was

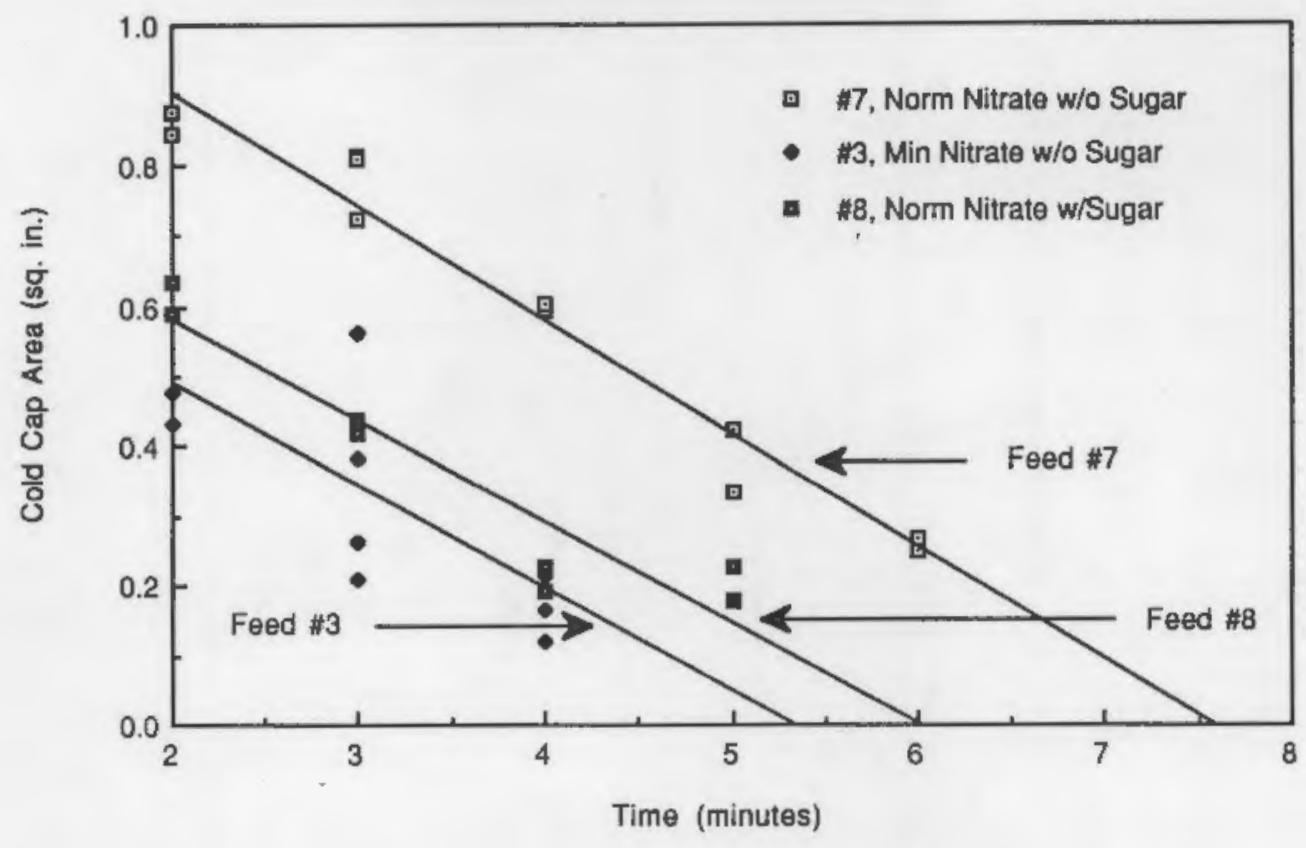

FIGURE 4.2. Melt Rate Data for Formate Glass-Former Feeds 


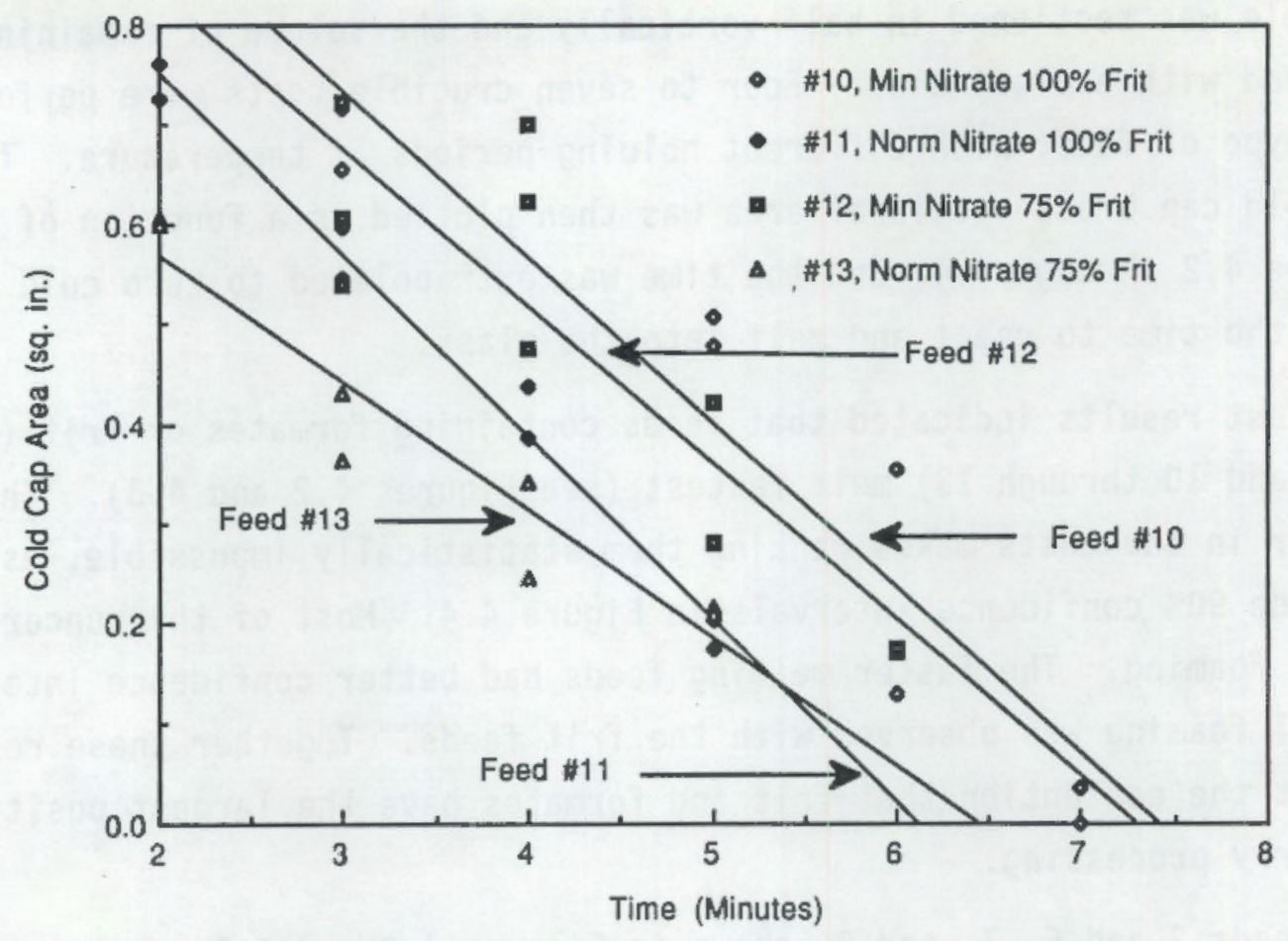

FIGURE 4.3. Melt Rate Data for Frit Feeds (all feeds contain sugar)

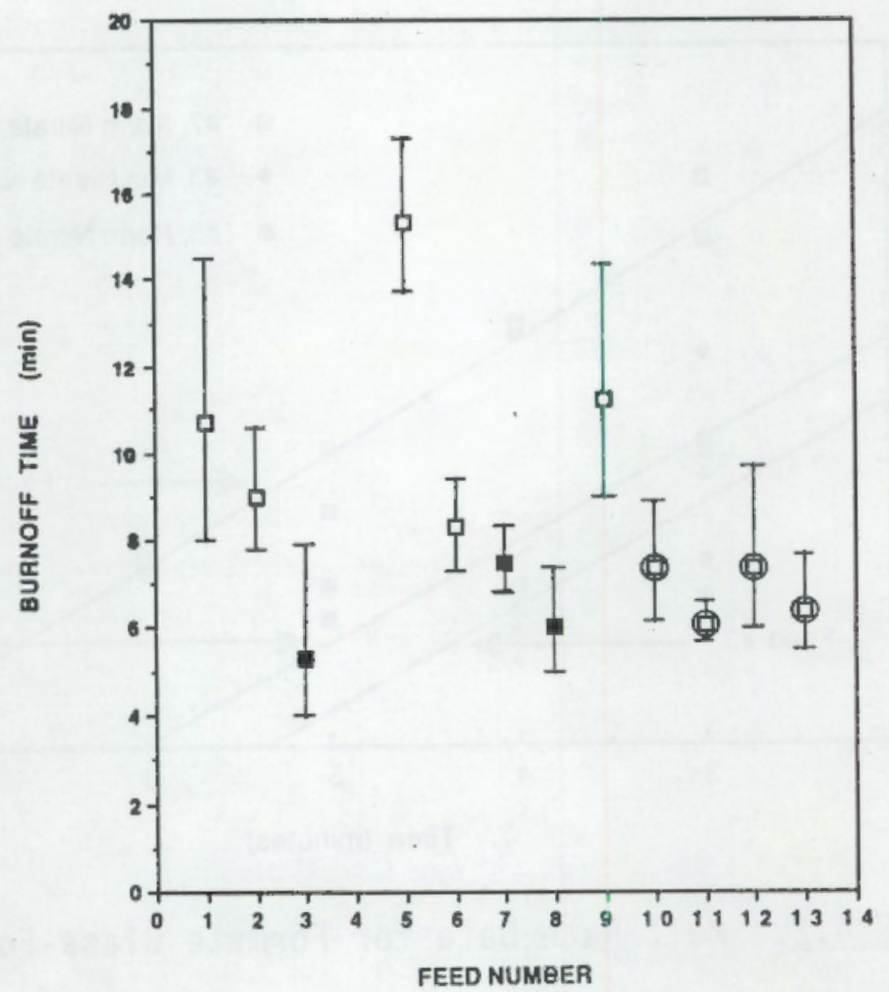

FIGURE 4.4. Comparison of Melt Rates with $90 \%$ Confidence Intervals 


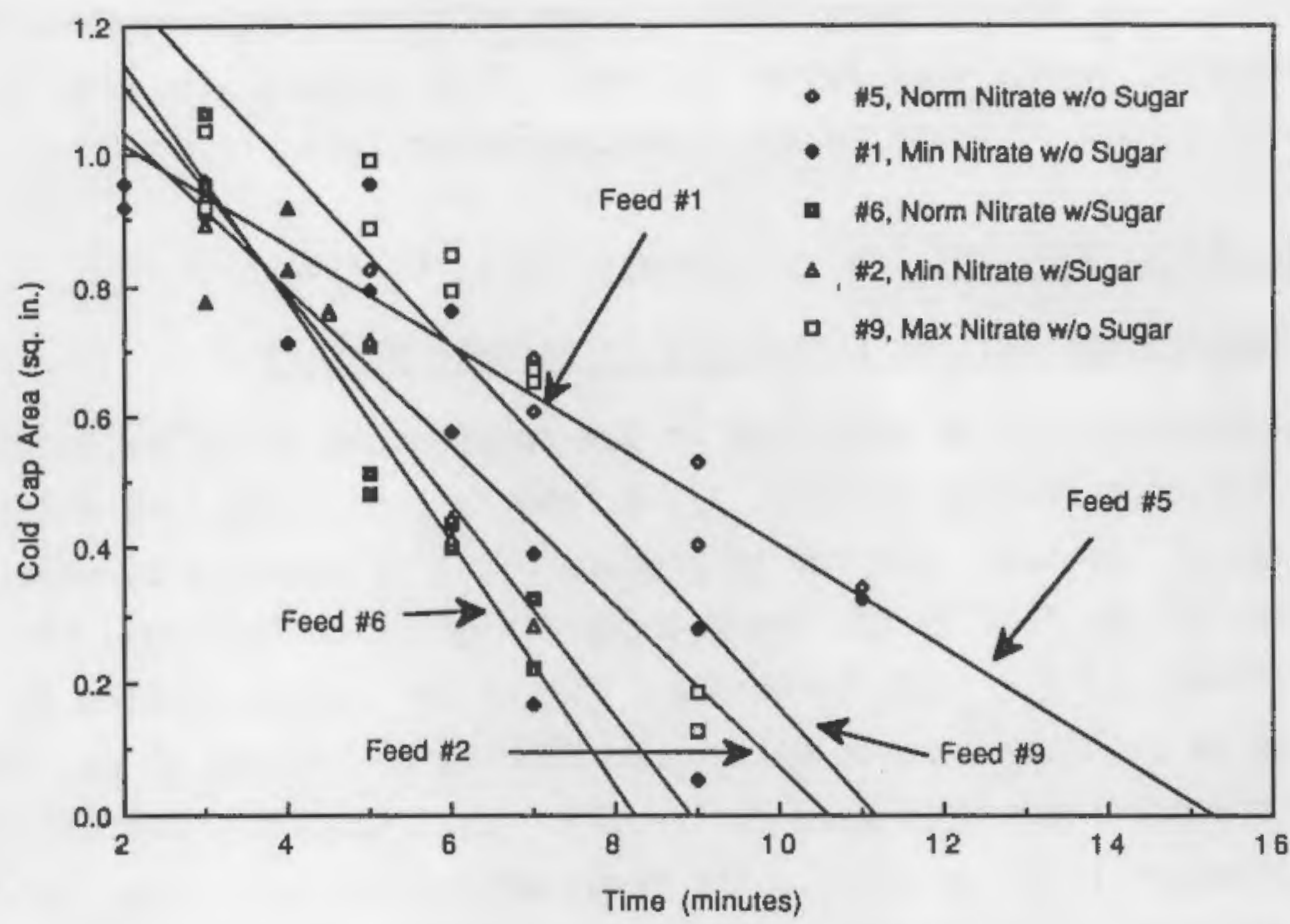

FIGURE 4.5. Melt Rate Data for Hydroxide Glass-Former Feeds

much more noticeable in them because of their high nitrate concentrations combined with glass-former chemicals that can react and release gaseous decomposition products. A suitable reductant (either formates or sugar) was added in each case, improving the processing characteristics by reducing the amount of foaming. The positive effect of the added reductant offset the negative effect of additional nitrates in feeds 6,7 , and 8 .

The slowest processing feeds were 1,5 , and 9 (see Figure 4.5). Foaming was extensive with feeds 5 and 9 because of the high nitrate concentration and the absence of reductant. Feed 1 also foamed but not so severely as feeds 5 and 9 because of its lower nitrate concentration. Foaming slowed processing rates due to the resulting poor heat transfer to the cold cap. The cold caps from the feeds containing sugar were found to be less dense and more porous than those from feeds that did not contain sugar.

These results indicate that West Valley flow sheet changes to reduce nitrate and sugar concentrations in the feed should be pursued. Sugar concentrations in the feed could be minimized by using formate glass-formers as 
reductants. The results suggest that lower nitrates (higher hydroxide) and lower reducing agents were faster melting. They suggest also that it was beneficial to use frit and to add formates rather than nitrates.

\subsection{ANALYTICAL MODELING - M. L. Elliott and L. L. Eyler}

\subsubsection{Theoretical Melting Enthalpies in Ceramic Melters}

One parameter to be optimized in the enhancement of melter production rate is the feed's oxide loading. If a feed is too dilute (low oxide loading), most of the heat required to produce glass is consumed by vaporization of water. If the feed is too concentrated (high oxide loading), the slurry becomes thick and difficult to handle. The oxide loading problem was addressed in high-bay ceramic melter run HBCM-86-2 (Nakaoka et a1. 1986). Three different feeds were used during this run: 415, 515, and 650 grams total oxide per liter ( $\mathrm{g} T \mathrm{TO} / \mathrm{L})$. The feeds were identical except for the water content in each. The results of the run indicated that the highest production rate was obtained using the $515 \mathrm{~g} \mathrm{TO} / \mathrm{L}$ feed. Of course, the highest feed rate was obtained using $415 \mathrm{~g} \mathrm{TO} / \mathrm{L}$, but the resulting glass production rate was low due to a more dilute feed.

To investigate this further, a simple heat balance was conducted on a hypothetical feed of varying oxide loading. The oxide loading was varied from $0 \mathrm{~g} \mathrm{TO} / \mathrm{L}(100 \%$ water) to $800 \mathrm{~g} \mathrm{TO} / \mathrm{L}$. A linear relationship was assumed between slurry density and oxide loading. The heat balance followed a fourstep process: 1) the heat required to raise the incoming slurry from ambient temperature $\left(25^{\circ} \mathrm{C}\right)$ to boiling $\left.\left(100^{\circ} \mathrm{C}\right) ; 2\right)$ the heat required to vaporize the water from the slurry; 3 ) the heat of reaction; and 4 ) the heat required to raise the resulting calcine from $100^{\circ} \mathrm{C}$ to a melt temperature of $1150^{\circ} \mathrm{C}$.

$$
Q=Q_{1}+Q_{2}+Q_{3}+Q_{4}
$$

where $Q_{1}(\mathrm{~J} / \mathrm{cc}$ slurry $)=\left.\rho C_{p}\left(T_{\text {boi1 }}-T_{\text {ambient }}\right)\right|_{\text {slurry }}$

$Q_{2}(J / c c$ slurry $)=\Delta H_{\text {vap }}\left(\rho_{\text {slurry }}-X_{\text {oxide }}\right)$

$Q_{3}(\mathrm{~J} / \mathrm{cc}$ slurry $)=\mathrm{X}_{\text {oxide }} \Delta \mathrm{H}_{\mathrm{rxn}}$ 


$$
\begin{aligned}
& Q_{4}(J / c c \text { slurry })=X_{\text {oxide }} C_{p}\left(T_{\text {melt }}{ }^{-T_{\text {boil }}}\right) I_{\text {calcine }} \\
& X_{\text {oxide }}=\text { grams total oxide per liter of slurry }
\end{aligned}
$$

The heats of reaction used to calculate $Q_{3}$ were acquired through the literature. The heat required to superheat the steam resulting from boiling the slurry was not included because only the heat needed in the melting process was of interest. The heat balance was conducted for feeds both with and without sugar. The sugar level used in the calculations was that of West Valley melter run $5 F-10,58 \mathrm{~g}$ sugar/L in $360 \mathrm{~g}$ TO/L feed. The mass of sugar per mass of oxide was held constant. The results of the heat balance indicate that the heat required to produce a gram of glass continues to decrease with increasing oxide loading. At low oxide loadings the benefit of concentrating the feed is significant. At higher oxide loadings $(>500 \mathrm{~g} T \mathrm{TO} / \mathrm{L})$ this benefit is reduced. The feed containing sugar requires less heat for melting due to the exothermic nature of sugar decomposition. If enthalpy were the only mechanism governing melt rates, the optimum feed would be pure oxide.

Obviously, some competing mechanism affects production rate at high oxide loadings. This mechanism is most likely related to slurry rheology; as oxide loading increases, the slurry becomes thicker and more difficult to handle. This was evident during HBCM-86-2 when pumping problems were incurred with the $650 \mathrm{~g} \mathrm{TO} / \mathrm{L}$ feed. Not only does the feed become more difficult to handle, but it also does not flow over the cold cap as freely. The slurry tends to stop flowing as it dries and forms a thick crust near the center of the melter. This makes a cold cap that is thick in the middle and thin on the outer edges. Melter surface area is not used efficiently: the thick coldcap center hinders heat transfer from the melt pool and decreases the melt rate.

To simply state the negative effects of rheology, the yield stress versus oxide loading has been overlaid with the effects of melting enthalpy and production rate as shown in Figure 4.6. The yield stress data points shown in Figure 4.6 come from analysis of the feeds from Burkholder, Jarrett, and Minor (1986), and the production rate data come from Nakaoka (1986). This plot qualitatively represents the negative effect of increasing oxide loading 


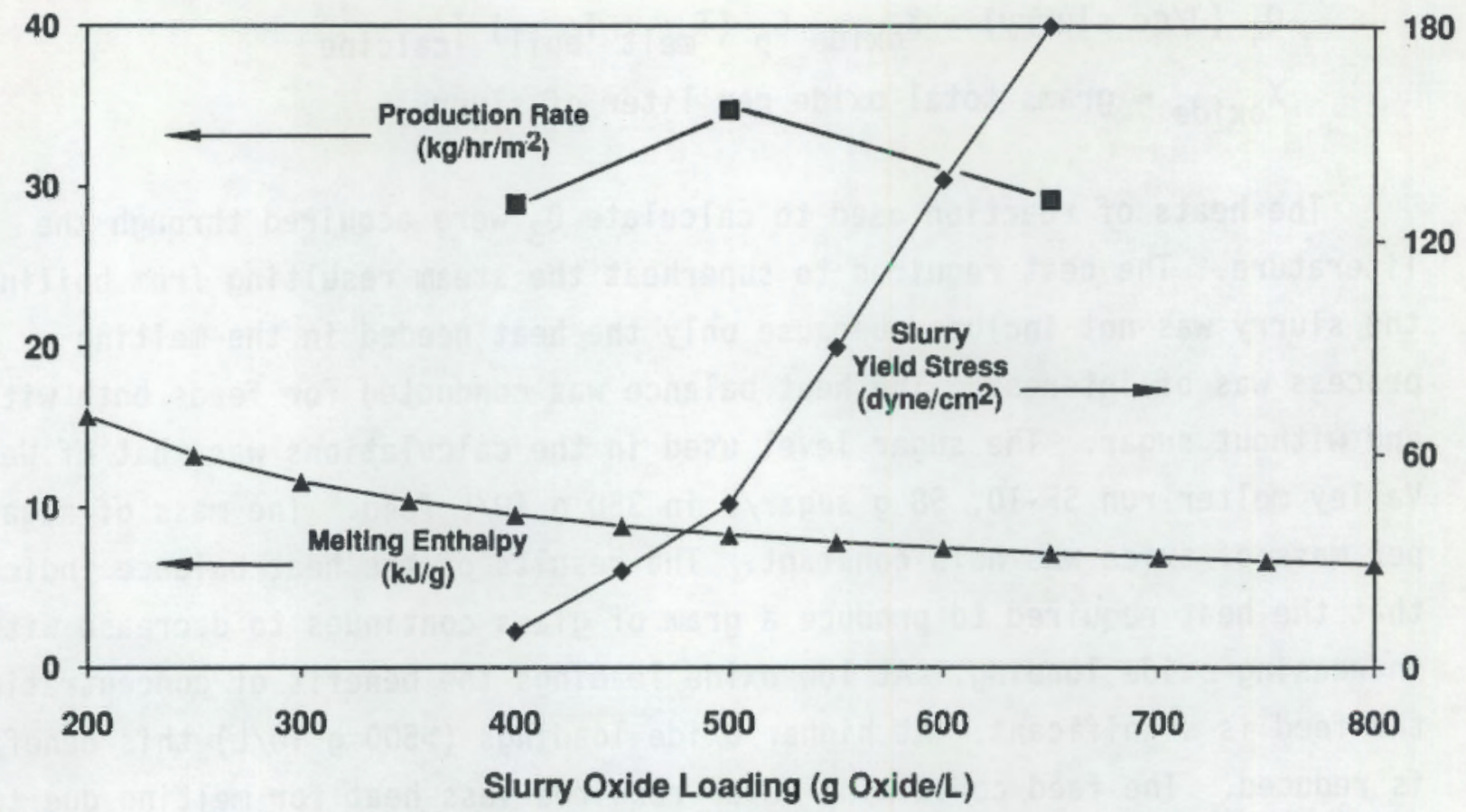

FIGURE 4.6. Melter Glass Production Rate, Slurry Melting Enthalpy, and Slurry Yield Stress Versus Slurry Oxide Loading

on slurry "spreadability"; it shows that there should be an optimum oxide loading where the two opposing mechanisms are balanced. The plot does not give a quantitative representation of the optimum oxide loading because the two $y$-axes are not of the same units. Further modeling is needed to yield a useful solution to this problem. This modeling should include a simplified model of the cold-cap hydrodynamics and drying mechanisms. (That is, how does the slurry flow over the cold cap as it dries from its original oxide loading to a calcine?)

\subsubsection{Effect of Cold-Cap Porosity on Thermal Conductivity}

In the cold cap, gas is released in chemical reactions that in turn may result in a porous layer. Primary gases that form in the pores are expected to be $\mathrm{NO}_{x}$ and/or $\mathrm{CO}_{2}$. Much work is referenced in the literature about specific porous, insulative materials. At present, because of uncertainty about the layer and its material properties, it is useful to examine the basic character of the thermal conductivity of a porous cold cap. 
Rohsenow and Hartnett (1973, pp. 3-128) reference an expression that incorporates the effect of solid conductivity, interstitial gas conductivity, pore diameter, and mean temperature. The expression is

$$
k_{\text {eff }}=(1-\alpha) k_{s}+\alpha k_{g}+4 d \sigma \bar{T}^{3}
$$

where $k_{\text {eff }}=$ an effective thermal conductivity of the porous layer

$$
\begin{aligned}
& k_{s}=\text { thermal conductivity of the solid } \\
& k_{g}=\text { thermal conductivity of the gas in the pores } \\
& \alpha=\text { porosity (= volume of pores/unit volume) } \\
& d=\text { is pore diameter } \\
& \vec{T}=\text { mean temperature, } k \\
& \sigma=\text { Stephan-Boltzmann constant. }
\end{aligned}
$$

The last term is a thermal radiation effect across the pores. Note that in this equation $\bar{T}=\left(T_{\text {hot }}+T_{\text {cold }}\right) / 2$. In a melter the porous layer may exist at different positions in the cold cap because nitrates release gas at higher temperatures than do other materials that may be present. In a melter the bulk glass temperature is typically $1150^{\circ} \mathrm{C}$ while the cold cap (boiling) surface is near $100^{\circ} \mathrm{C}$. Thus the hot, cold and average temperatures would be within this range.

The limit of the normalized effective thermal conductivity, $k_{e f f} / k_{s}$, of a porous layer is greater than 1 for the cases of high gas thermal conductivity or low gas conductivity with low porosity. The enhancement comes from thermal radiation across the pores. Furthermore, it also can be shown that there will be enhancement $\left(k_{e f f} / k_{s}>1\right)$ as long as relative radiation is greater than the porosity fraction. The condition can be generalized further so that enhancement will occur for

$$
\frac{4 a d \vec{T}^{3}}{k_{s}}>a\left[1-\frac{k_{g}}{k_{s}}\right]
$$


If the inequality is not satisfied, then heat transfer through the layer will decrease (e.g., $\left.k_{e f f} / k_{s}<1\right)$. By plotting these results it can be shown that the radiation contribution to conductivity is as significant as the conductivity of interstitial gas at small pore diameters and becomes more significant as pore volume increases. For pore diameters on the order of $1 \mathrm{~mm}$, the radiation component becomes equivalent to the thermal conductivity of glass. It should also be noted that the radiation component is a strong function of temperature, increasing a factor of 40 (at fixed pore diameter d) with an increase in average temperature of 100 to $1000^{\circ} \mathrm{C}$.

An increased void fraction of the cold cap decreases solid conductivity and increases interstitial gas thermal conductivity. The order of magnitude of each is directly proportional to porosity ranging from 0 to about 0.8 . The sensitivity of the effective conductivity to change in void fraction is proportional to the difference in $\mathrm{k}_{\mathrm{g}}-\mathrm{k}_{\mathrm{s}}$. The point of least sensitivity is for $k_{g}=k_{s}$; e.g., the gas has the same conductivity as the solid.

The significance of these results is that if gas voids are created and a porous layer develops in a hotter zone of the cold cap, effective heat transfer will be enhanced more than if they are created in a colder zone. This is because of thermal radiation across the voids. Thermal conductivity of the gas in the voids has only a secondary effect on $k_{\text {eff }}$, unless it is of the same order as the solid conducting material. Because glass has a conductivity at least an order of magnitude greater than expected interstitial gases, this latter is not expected to occur readily. These calculations consider the cold cap only as a porous solid/gaseous matrix in which gases are trapped. A preferable cold cap would be thin and flexible and would release all gases from the decomposing feed as they are generated within it.

\subsection{PILOT-SCALE TESTING - R. K. Nakaoka, J. M. Perez, Jr., and C. C. Chapman}

A pilot-scale melter test was completed using the pilot-scale ceramic melter (PSCM) at PNL as part of the effort to enhance glass production rate. The experiment, PSCM-24, was statistically designed to evaluate the effect of bulk glass temperature, feed oxide loading, and mixing by air-bubbling. The temperature was varied from 1080 to $1225^{\circ} \mathrm{C}$, and the oxide loading was varied 
from 440 to $660 \mathrm{~g} \mathrm{TO} / \mathrm{L}$. During the high-temperature portion of the run, a maximum feed rate of about $110 \mathrm{~L} / \mathrm{hr}$ was maintained with an oxide Toading of $660 \mathrm{~g} \mathrm{TO} / \mathrm{L}$. Thus the $\mathrm{glass}$ production rate exceeded $66 \mathrm{~kg} / \mathrm{hr}$. On a normalized basis this translates into $130 \mathrm{~L} / \mathrm{hr}-\mathrm{m}^{2}$ and $86 \mathrm{~kg} / \mathrm{hr}-\mathrm{m}^{2}$. This exceeds the previous records of $120 \mathrm{~L} / \mathrm{hr}-\mathrm{m}^{2}$ and $55 \mathrm{~kg} / \mathrm{hr}-\mathrm{m}^{2}$, respectively, which used plenum heating whereas this test did not. It exceeds the previous best HWVP result, PSCM-23, which had rates of $54 \mathrm{~L} / \mathrm{hr}-\mathrm{m}^{2}$ and $38 \mathrm{~kg} / \mathrm{hr}-\mathrm{m}^{2}$. This is $240 \%$ over the previous HWVP slurry rate and $225 \%$ over the glass rate for the PSCM melter.

For the low-temperature test segment, $1080^{\circ} \mathrm{C}$, the processing rate was estimated to be less than $30 \mathrm{~L} / \mathrm{hr}\left(40 \mathrm{~L} / \mathrm{hr}-\mathrm{m}^{2}\right.$ and $\left.52 \mathrm{~kg} \mathrm{glass} / \mathrm{hr}-\mathrm{m}^{2}\right)$. This was unexpected. The results from the dilute feed and bubbling segments of the test were inconclusive due to mechanical problems. Technically significant conclusions cannot be made about this test until the feed and glass compositions are known. The major contrast between the test segments is believed to contain some key information. More thorough data reduction and analysis are needed and will be completed during FY 1990.

\subsection{REFERENCES}

Burkholder, H. C., J. H. Jarrett, and J. E. Minor. 1986. LFCM Vitrification Technology Quarterly Progress Report October-December 1985. PNL-5904-1, Pacific Northwest Laboratory, Richland, Washington.

Nakaoka, R. K., et al. 1986. Hanford Waste Vitrification Plant Nonradioactive Liquid-Fed Ceramic MeTter Testing for FY 1986. RHO-RE-CR-17P/ HWVP-86-HLVID, Rockwell Hanford Operations, Richland, Washington.

Rohsenow, W. M., and J. P. Hartnett. 1973. Handbook of Heat Transfer. McGraw-Hil1, New York. 


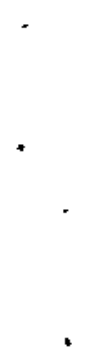




\subsection{MISCELLANEOUS WASTE TREATMENT}

R. D. Peters - Manager

\subsection{OBJECTIVE}

The objective of the Miscellaneous Waste Treatment Program within the Contaminated Materials Treatment Program is to design and construct a plasma furnace for treating contaminated or activated metals. Various technologies for volume reduction of Greater-than-Class-C (GTCC) metals have been evaluated in predecessor programs at PNL. Metal melting, specifically via plasma heating, has emerged as a promising approach.

\subsection{INTRODUCTION}

EarTy in FY 1989, a report on activities conducted during FY 1987 was completed which was ultimately published in a waste management journal, Radioactive Waste Management and the Nuclear Fuel Cycle. The report described a successfu1 test in which hardware from a simulated pressurized water reactor assembly was melted into a dense ingot using a vendor-owned research and development plasma furnace. The work in FY 1989 has been primarily to design a plasma furnace with similar melting capabilities, but with remote features so that it can treat highty radioactive waste metal.

Possible missions for the plasma furnace include the treatment of 1) irradiated metals from decommissioned commercial reactor cores and 2) spent fuel assembly hardware from consolidation of fuel rods. Other uses that became apparent in FY 1989 are the treatment of remote-handled transuranic (TRU) waste stored at Hanford and the melting of TRU waste stored in 55-gal drums at several DOE sites. A description of the plasma furnace and its capabilities was submitted to PNL's Research, Development, Demonstration Testing and Evaluation (RDDT\&E) 5-year plan. Other accomplishments of the program are provided below.

\subsection{DESIGN PROGRESS}

The major accomplishments in FY 1989 were to 1) prepare the functional design criteria for the plasma furnace, 2) establish a contract with a 
manufacturer to design and build the plasma torch, 3) develop design concepts for the furnace, and 4) initiate design on the furnace and torch.

The key design criteria for the torch are summarized as follows:

- Feedstock is radioactive metal having a maximum cross-section of 24 in.

- Nominal metal melting rate is $180 \mathrm{lb} / \mathrm{hr}$.

- The furnace shall be remotely operable with a crane and impact wrench.

- Continuously exposed equipment in the process cell shall be radiation-resistant ( $10^{6}$ to $10^{7} \mathrm{R} / \mathrm{hr}$ exposure).

- The work-force requirement will be low, one or two operators.

- Molten metat is to be drip-cast into the canister.

- Secondary waste streams will be minimal. Collected dust from the off-gas system will be recycled to the furnace.

A conceptual design of the furnace is given in Figure 5.1. Waste metal is fed horizontally and is melted by the torch into a hearth. The hearth remains in a fixed position, which is advantageous in that mechanical complexity is avoided. When the hearth is full, the torch melts a frozen plug of metal at the hearth's pouring tip. This allows the molten metal to flow into the waste canister. When the canister is full, it is lowered and moved out of the way by a trolley and is replaced by an empty canister. The power supply, gas suppiy, and control systems will be situated in a nonradioactive, manned access area, while the furnace and torch will be in a radiation cell. The furnace chamber atmosphere is kept inert with argon gas to minimize oxidation of the molten metal and prevent slag formation.

The furnace exhaust will discharge to a gas-cleaning system. The major system components are a submerged bed scrubber (SBS), a heater, and a highefficiency particulate air (HEPA) filter. Solid aerosols captured by the SBS can be collected and fed through the furnace, thus minimizing secondary waste streams. 


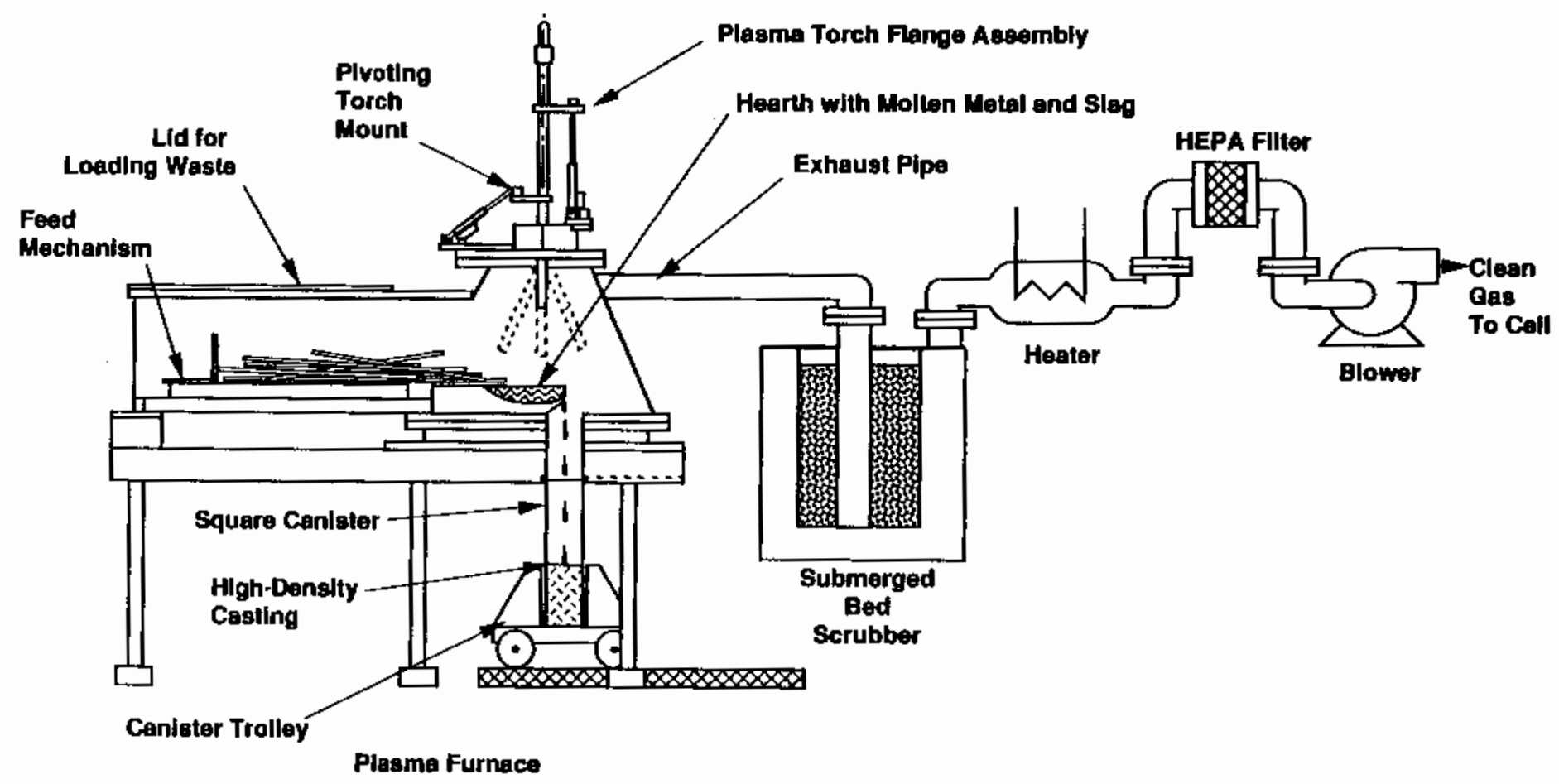

FIGURE 5.1. Waste Treatment Plasma Furnace and Off-Gas System 
Criteria supplied to the torch manufacturer call for a transferred arc with a torch power rating of at least $250 \mathrm{~kW}$. The plasma-forming gas will be an inert gas such as argon or helium. The torch has a water-cooled ram and a graphite end-piece which is slowly consumed during operation. The low-cost graphite portion can be remotely accessed for replacement by vertically withdrawing the ram from the top of the furnace.

\subsection{STATUS AND PLANS}

Detailed design of the torch and the furnace is now under way. PTans call for the design to be finished by early FY 1990, at which time bids will be sought on fabrication. The unit would be installed and tested in a nonradioactive facility in FY 1991 and FY 1992. Remote cell installation is planned for FY 1993, and treatment demonstrations will occur in FY 1994 through FY 1996. Decommissioning is planned to take place no sooner than FY 1997. 


\section{DISTRIBUTION}

No. of

Copies

OFFSITE

12 DOE/Office of Scientific and Technical Information

3 DOE Office of Civilian Radioactive Waste Management Forrestal Building Washington, DC 20585

ATTN: L. Barrett, RW-40

J. W. Bartlett, RH-1

R. Stein, RH-30

T. B. Hindman, DP-12

DOE Office of Defense Programs GTN

Washington, DC 20545

8 DOE Office of Environmental

Restoration and Waste

Management

GTN

Washington, DC 20545

ATTN: J. E. Baublitz, EM-50

K. A. Chacey, EM-30

J. A. Coleman, EM-35

C. R. Cooley, EM-55

J. J. Fiore, EM-423

M. Frei, EM-34

T. W. McIntosh, EM-343

H. F. Walter, EM-343

J. 0 . Bunting

Division of High-Level Waste Nuclear Regulatory Commission Washington, DC 20555

J. M. Taylor

Office for the Executive

Director for Operations

Mail Station 17-H1

Nuclear Regulatory Commission

Washington, DC 20555
No. of

Copies

W. F. Holcomb

Environmenta1 Protection Agency

Office of Radiation Programs (ANR-460)

401 M Street S.W.

Washington, DC 20460

P. A. Saxman

DOE Albuquerque Operations Office

P.0. Box 5400

A1buquerque, NM 87185

3 DOE Idaho Operations office 785 DOE Place

Idaho Falls, ID 83402

ATTN: C. R. Enos

M. W. Shupe

J. E. Solecki

M. R. Jugan

DOE Oak Ridge Operations Office

P.0. Box E

Oak Ridge, TN 37830

F. T. Fong

DOE San Francisco Operations 1333 Broadway

OakTand, CA 94612

W. T. Goldston

DOE Savannah River Operations Office

P.0. Box A

Aiken, SC 29801

E. Maestas

DDE West Valley Project

P.0. Box 191

Hest Va]Tey, NY 14171 
No. of

Copies

C. P. Gertz

DOE Yucca Mountain Project

Phase 2

Suite 200

101 Convention Center Orive

Las Vegas, NV 89109

M. J. Steindler, CMT-205

Argonne National Laboratory

9700 South Cass Avenue

Argonne, IL 60439

C. S. Abrams

Argonne National Laboratory

P.0. Box 2528

Idaho Falls, ID 83401

2 Battelle Memorial Institute

$505 \mathrm{King}$ Avenue

Columbus, OH 43201

ATTN: W. A. Carbeiner

R. A. Nathan

L. D. Ramspott, L209

Lawrence Livermore National Laboratory

University of California

P.0. Box 808

Livermore, CA 94550

D. T. Oakley, MS-J521

Los A] amos National Laboratory

P.0. Box 1663

Los Alamos, NM 87545

4 Oak Ridge National Laboratory

P.0. Box Y

Oak Ridge, TN 37830

ATTN: W. D. Burch

R. T. Jubin

L. J. Mezga

D. W. Turner
No. of

Copies

2 Sandia Laboratories

P.0. Box 5800

Albuquerque, NM 87185

ATTN: R. W. Lynch, Dept. 6300

Technical Library

J. R. Berreth

Westinghouse Idaho Nuclear

Co., Inc.

P.0. Box 4000

Idaho Falls, ID 83401

5 Westinghouse Savannah River Co.

Savannah River Site

Aiken, SC 29801

ATTN: R. G. Baxter

M. D. Boersma, $77341 \mathrm{~A}$

J. R. Knight, $773 \mathrm{~A}$

M. J. Plodinec, 773A

C. T. Randal1, 7042

A. D. Rodgers

Mail Stop 2411

EG\&G Idaho

P.0. Box 1625

Idaho Falls, ID 83415

R. F. Williams

Electric Power Research Inst itute

$3412 \mathrm{Hillview} \mathrm{Avenue}$

P.0. Box 10412

Palo Alto, CA 94303

4 West Valley Nuclear

Services Co.

P.0. Box 191

West Valley, NY 14171

ATTN: R. R. Borisch

J. Buggy

J. M. Pope

R. A. Thomas 
No. of

Copies

S. G. Harbison

New York State Energy Research

\& Development Authority

P.0. Box 191

West Valley, NY 14171

I. L. White

New York State Energy Research

\& Development Authority

Empire State Plaza

Albany, NY 12223

\section{ONSITE}

6 DOE Richland Operations office

M. J. Furman

R. E. Gerton

J. C. Peschong

S. K. Moy

E. C. Norman

G. W. Rosenwald

6 Westinghouse Hanford Company

J. M. Henderson

R. E. Lerch

R. A. Smith

E. T. Weber

D. D. Wodrich

B. A. Wolfe

50 Pacific Northwest Laboratory

C. R. Allen

R. P. Alten

W. F. Bonner

L. A. Bray

R. A. Brouns

J. L. Buelt

H. C. Burkholder (2)

C. C. Chapman

L. L. Clark
No. of

Copies

Pacific Northwest Laboratory (contd)

J. R. Divine

D. L. Eggett

M. L. Elliott

R. W. Goles

W. 0 . Heath

L. K. Holton, Jr.

P. R. Hrma

D. E. Janke

J. H. Jarrett

Y. B. Katayama

D. E. Kurath

D. A. Lamar

D. E. Larson

J. L. McE]roy

G. B. Mellinger

R. F. Nakaoka

J. M. Perez, Jr.

R. D. Peters

G. F. Piepe]

J. A. Powel1

B. A. Pulsipher

W. A. Ross (5)

J. M. Seay

S. C. Slate

R. I. Smith

J. E. Surma

C. K. Thornhill

R. E. Westerman

J. H. Westsik

K. D. Wiemers

Publishing Coordination

Technical Report Files 


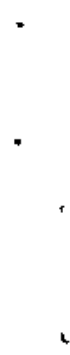

